\title{
PROCEEDINGS OF THE AUSTRALIAN SOCIETY FOR REPRODUCTIVE BIOLOGY
}

\author{
SIXTH ANNUAL GONFERENGE, 26Tн то 28тн AUGUST 1974
}

\author{
Held at the Medical Centre, \\ University of Melbourne, Victoria \\ Edited on behalf of the Society by \\ B. M. BINDON \\ Session 1 \\ Comparative Mammalian Reproduction \\ Chairman: DR J. O'SHEA
}

Sugars of the accessory sexual secretions of males of marsupial and eutherian species. J. G. Rodger and I. G. WhIte, Department of Veterinary Physiology, University of Sydney, N.S.W. 2006, Australia.

Studies of Australian marsupials have shown that glucose rather than fructose is the major sugar of the prostate gland (Rodger \& White, 1974a) and that glucose, inositol and $\mathrm{N}$-acetylglucosamine occur in ejaculated seminal plasma (Rodger \& White, 1974b). The present paper gives data on the glandular origin of the seminal $\mathrm{N}$-acetylglucosamine and extends the study of the biochemistry of the prostate to additional marsupial species. The results of analyses of the $\mathrm{N}$-acetylhexosamine levels in the semen of some eutherian species are also presented.

The main source of $\mathrm{N}$-acetylglucosamine in marsupials with a three segmented prostate of the macropod-Trichosurus type, is the central segment. In bandicoots, both the ventral and dorsal segments of the prostate contain quite high levels of $\mathrm{N}$-acetylglucosamine, but the level in the smaller ventral segment is approximately twice that in the other segment.

Analyses of glucose and anthrone-reactive material in the prostate of the grey kangaroo, tammar wallaby and long and short-nosed bandicoots indicate very similar patterns to those described for the bush-tailed possum and red kangaroo (Rodger \& White, 1974a). The grey kangaroo pattern is almost identical to that of the red kangaroo with high glucose levels in the posterior segment. The tammar wallaby prostate has low glucose and anthrone levels in all segments, as does the possum. The glucose figures for the bandicoot fall between the two groups and the prostate of the bandicoot also contains large amounts of anthrone reactive material other than glucose.

The results thus far obtained for assays of $\mathrm{N}$-acetylhexosamine in eutherian species (bull, boar, rabbit, dog and man) indicate that in all species free 
$\mathrm{N}$-acetylhexosamines are absent from the semen, except that of man which contains 20 to $40 \mathrm{mg} / 100 \mathrm{ml}$ seminal plasma.

The data presented confirm the widespread occurrence of $\mathrm{N}$-acetylhexosamine in the accessory sexual secretions of Australian male marsupials and suggest that this material is a characteristic constituent of the semen of marsupials but not of other mammals.

\section{REFERENCES}

Rodger, J. G. \& White, I. G. (1974a) F. Reprod. Fert. 39, 267-273.

Rodger, J. G. \& White, I. G. (1974b) F. Reprod. Fert. 39, 383-386.

Reproduction in the platypus, Ornithorhynchus anatinus, with particular reference to the evolution of viviparity. R. L. HUGHEs, F. N. GARrick and C. D. Shorey, * School of Zoology, University of New South Wales, and ${ }^{*}$ Department of Histology and Embryology, University of Sydney, Australia.

The surface of the platypus ovary exhibits only small follicles of less than $2.0 \mathrm{~mm}$ in diameter for much of the year and during the summer months the testes of the male undergo involution.

Synchronization of gametogenic activity proceeds during a relatively restricted breeding season in the late spring (September-October) at the study area near Yass, N.S.W.

In comparison with their dormant state, the testes of the platypus are dramatically enlarged when producing spermatozoa and a substantial quantity of $17 \beta$-hydroxysteroid is present in the testicularvenous plasma. The chromatographic mobility of this compound on paper using the Bush-A system is consistent with the mobility of testosterone.

Ovarian follicles, during the immediate pre-ovulatory period, have a diameter of between 4.0 and $4.5 \mathrm{~mm}$ and the newly ovulated egg of about $3 \mathrm{~mm}$ in diameter acquires a mucoid coat of acidic glycoprotein and the first component of its ovokeratinous shell during its passage through the Fallopian tube to the uterus. A prolonged but as yet undetermined period of intrauterine development then follows. This is accompanied by a fivefold increase in the diameter of the minor axis of the egg and embryonic development proceeds up to a prefetal somite stage.

Two fully developed intrauterine eggs were recovered from a female captured on 28 September 1973 and sampled 1 week later. The eggs were oval and approximately of equal size. The major and the minor axes of the parchment-like shell were 17 and $15 \mathrm{~mm}$ respectively. The prefetal embryo had an overall length of $15 \mathrm{~mm}$ and possessed about twenty pairs of somites. The anterior portion of the neural tube exhibited well-differentiated optic vesicles and rudiments of a head fold had developed. Although no embryonic blood vessels were seen, blood islands had begun to form.

Although the platypus is oviparous its reproductive processes include components found in the viviparous mammals.

The development of the egg occurs in the presence of a CL. The luteal cells have a comparable ultrastructure to those of viviparous mammals and luteal necrosis was not evident in the animal with the fully developed eggs. 
In the platypus, the endometrial ultrastructure in the immediate preovulatory period and throughout gestation is comparable to the progestational condition of the endometrium of a viviparous mammal in the luteal phase.

The ultrastructural observations on the luteal cells and the uterine endometrium of the platypus are correlated with high levels of steroid hormones during pregnancy (Garrick, Hughes, Drinan, Cox \& Shorey, 1975).

Although the similarities between the reproductive processes of the platypus and those of the viviparous mammals have probably been independently evolved, they exhibit a remarkable degree of convergence and may also represent the type of preadaptation which might have been present in the ancestors of the viviparous mammals.

Ultrasructural observations of the platypus egg shell have shown that, as in other amniote vertebrates with shelled eggs, it is highly porous and this is obviously of primary importance as a preadaptation for viviparity.

\section{REFERENCE}

Garrick, F. N., Hughes, R. L., Drinan, J. P., Cox, R. I. \& Shorey, G. D. (1975) Aust. Mammal. 4, (in press).

Progestagens and oestrogens in peripheral plasma of the platypus, Ornithorhynchus anatinus. F. N. GARRICK, ${ }^{*}$ J. P. DrINAN $\dagger$ and R. I. Cox, $\uparrow$ * School of Zoology, The University of New South Wales, P.O. Box 1, Kensington, N.S.W. 2033, and †C.S.I.R.O., Division of Animal Physiology, Prospect, P.O. Box 239, Blacktown, N.S.W. 2148, Australia.

From their detailed histological observations, Hill \& Gatenby (1926) inferred a dual endocrine rôle for the corpus luteum in the regulation of uterine function and pregnancy in the Monotremata. The recent acquisition of live platypus, especially the first pregnant animal collected since the turn of the century, has enabled an initial investigation to be made of some steroids present in plasma of this species. The samples examined (Table 1) were obtained by cardiac puncture from a full-term pregnant platypus (Carrick, Hughes, Drinan, Cox \& Shorey, 1975), a mature female unilaterally ovariectomized to remove the functional ovary, two non-pregnant mature females, and a mature male in active spermatogenesis.

Progestagens were estimated by competitive protein-binding (CPB) assay using corticosterone-binding globulin (CBG) (Thorburn \& Schneider, 1972). All plasma examined yielded CBG-reactive material that was resolved into at least two major bands by chromatography on Sephadex LH 20 columns. The first band had a progesterone-like mobility, while the second was eluted in the region of $17 \alpha$-hydroxyprogesterone and appeared to contain more than one compound. The pregnant animal had the highest levels in both bands. The same plasmas were extracted, chromatographed on alumina and analysed for oestrogens by CPB assay using sheep uterine cytosol (Shutt \& Cox, 1973). An appreciable quantity of oestradiol-17 $\beta\left(\mathrm{E}_{2} \beta\right)$ was found in the plasma of the pregnant animal; substantially less was present in the other samples. Neither oestrone $\left(E_{1}\right)$ nor oestriol were detected. Portions of these plasma extracts were also radioimmunoassayed with specific antisera prepared using 6-carboxy- 
methoxime derivatives of $\mathrm{E}_{2} \beta$, oestradiol-17 $\alpha\left(\mathrm{E}_{2} \alpha\right)$ and $\mathrm{E}_{1}$. These radioimmunoassays confirmed the presence of $\mathrm{E}_{2} \beta$ and the absence of $\mathrm{E}_{1}$, and also demonstrated the absence of $E_{2} \alpha$. An ethyl acetate extract of the pregnancy plasma was chromatographed on Sephadex LH 20 and split fractions were assayed using both cytosol and antisera. The presence of relatively large amounts of other oestrogen-like compounds was indicated: about $2 \mathrm{ng} / \mathrm{ml}$ of cytosol-reactive material, expressed as $\mathrm{E}_{2} \beta$ equivalents.

Table 1. Progesterone and oestradiol-17 $\beta$ concentrations in the peripheral plasma of the platypus

\begin{tabular}{|c|c|c|c|c|c|}
\hline \multirow[t]{2}{*}{ Steroid $(n g / m l)$} & \multirow{2}{*}{ 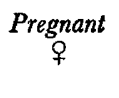 } & \multicolumn{2}{|c|}{ Non-pregnant } & \multirow{2}{*}{$\begin{array}{c}\text { Ovariectomized } \\
\text { o }\end{array}$} & \multirow[t]{2}{*}{ Male } \\
\hline & & $\$ 1$ & \$2 & & \\
\hline $\begin{array}{l}\text { Progesterone } \\
\text { Oestradiol-17 } \beta\end{array}$ & $\begin{array}{c}10 \cdot 4 \\
0 \cdot 16\end{array}$ & $\begin{array}{l}2 \cdot 1 \\
0.01\end{array}$ & $\overrightarrow{0.09}$ & $\begin{array}{l}5 \cdot 2 \\
0 \cdot 07\end{array}$ & $\begin{array}{l}6 \cdot 1 \\
0.04\end{array}$ \\
\hline
\end{tabular}

* Following LH 20 chromatography.

These data show that substantial quantities of progestagens and oestrogens are present in peripheral plasma of the platypus and that the greatest concentrations were found in the one pregnant animal available.

\section{REFERENGES}

Carrick, F. N., Hughes, R. L., Drinan, J. P., Cox, R. I. \& Shorey, C. D. (1975) Aust. Mammal. 4, (in press).

Hill, J. P. \& Gatendy, J. B. (1926) Proc. zool. Soc. Lond. 47, 715-763.

ShuTt, D. A. \& Cox, R. I. (1973) Steroids, 21, 565-582.

Thorburn, G. D. \& Schneider, W. (1972) F. Endocr. 52, 23-36.

The breeding cycle of the Weddell seal (Leptonychotes weddelli) at McMurdo Sound, Antarctica. M. S. R. SмIтн, School of Anatomy, University of New South Wales, Kensington, N.S.W. 2033, Australia.

The first seals entering McMurdo Sound in the spring are pregnant females returning to the pupping areas on the west coast of Ross Island. A few males accompany the females at this time, to the small areas of open water. The only males present in the immediate vicinity of the females appear to be dominant bulls. The number of seals within a given area, during the pupping season, is probably limited by the number of ice holes and the consequent competition for these holes probably excludes all but dominant males and pregnant females.

Initiation of spermatogenesis in the male appears to be influenced by increasing day length but the mechanism by which the seminiferous epithelium degenerates to the non-breeding condition after active spermatogenesis is unknown but the termination of sperm production at the end of December is abrupt.

Parturition occurs at a time when the sea ice in McMurdo Sound is stable and the tide cracks are open especially around islands and rocky outcrops. It commences in spring and correlates with the rise in mean monthly temperatures $\left(-23.3^{\circ} \mathrm{C}\right.$, September; $-19 \cdot 0^{\circ} \mathrm{C}$, October; $-9.9^{\circ} \mathrm{C}$, November $)$. 
Natural selection will tend to fix the timing of fertilization and birth at the most favourable times of the year. In mammals these two events in the annual cycle are linked by the period of gestation. The end points cannot be shifted independently of each other and consequently a compromise must be reached between the optimum time of birth and fertilization. However, this does not hold if the gestation period can be contracted or extended. One mechanism for extending the gestation period without modifying the duration of fetal development is that of delayed implantation. This has been utilized by several pinnipeds.

The timing of birth and fertilization in the Weddell seal is critical. Births must occur when temperatures are not too cold and when the sea ice is stable. These conditions occur between October and December. Parturition during this period allows the pup to be weaned and to develop sufficiently to stand a chance of surviving the winter. Changes in photoperiod also affect the female cycle and this is particularly related to delayed implantation. For 6 weeks after parturition the females remain aggregated in small groups and guide the pups through one of the most critical periods of their life history. Fertilization follows lactation and this minimizes physiological strain on the female. The elephant seal (Laws, 1956; Carrick, Csordas, Ingham \& Keith, 1962) was shown to have a post-partum fertilization but this may be due to the establishment of harems by dominant males and also the less demanding environmental conditions. Fertilization in the Weddell seal also occurs before the onset of the moult which commences in early December and continues for about 6 weeks. To get the highest percentage of females fertilized it is probably necessary for this event to happen before the major dispersal of seals with the onset of the break up of sea ice in McMurdo Sound.

It is therefore suggested that the environment in the Antarctic ecosystem has a considerable effect on the breeding cycle of the Weddell seal.

\section{REFERENGES}

Garrick, R., Gsordas, S. E., Ingham, S. E. \& KeIth, K. (1962) C.S.I.R.O. Wildl. Res. 7, 119-160. Laws, R. M. (1956) Falk. Is. Dep. Surv. Sci. Rep. 15, 1-66.

The influence of rams on the fertility of the ewe. T. W. KNIGHT, D. R. Lindsay and C. M. Oldham, Department of Animal Sciences \& Production, University of Western Australia, Nedlands, W.A. 6009, Australia.

The mating and lambing performance of ewes in forty-six commercial flocks in south Western Australia were studied over the period 1969-73. The rams were fitted with Sire sine harnesses and crayons. The colour of the crayons was changed every 2 weeks and the ewes marked in each 2-week interval were recorded. Ewes were identified as having lambed by the method of Dun (1963).

The conception rate of the ewes mated in the first 2 weeks of mating was $8.4 \%$ lower $(P<0.001)$ than for ewes mated for the first time in the second 2 weeks of mating. This difference in the conception rate was not influenced by the age of the ewe but it did vary over the breeding season. In October and November, the conception rate of ewes mated in the first 2 weeks of mating was $19.2 \%(P<0.001)$ lower than the ewes mated for the first time in the second 
2 weeks. This difference in conception rate declined to $4.1 \%$ in February and March but was still significant $(P<0.01)$.

The return rates indicated that most of the difference in the conception rate could be attributed to a reduced fertilization and/or early embryo survival of ewes mated in the first 2 weeks as compared with ewes mated in the second 2 weeks of mating.

The possibility that the rams were influencing the fertility of the ewes to cause this difference in conception rate was investigated on four commercial flocks. Half of the ewes in each flock were placed with teaser rams for 1 month prior to mating, while the other half of the flock was kept isolated from rams. The return rates of the teased ewes and their lambing performance indicated that the fertility of the ewes mated in the first and second 2 weeks of mating were similar. These preliminary results suggest that association with rams for 4 weeks before fertile mating can influence the fertility of the ewe.

REFERENGE

Duv, R. B. (1963) Aust. F. exp. Agric. Anim. Husb. 3, 228-231.

SEssion 2

Comparative Mammalian Reproduction

Chairman: Professor C. W. EMMENS

James Goding Memorial Lecture

The ovine and bovine oestrous cycle

An appreciation of J. R. Goding's contribution to the oestrous cycle. I. A. Cumming, Department of Agriculture, Victoria S. S. Cameron Research Laboratory, State Research Farm, Werribee, Victoria 3030, Australia.

\section{Session 3}

MALE REPRODUGTION

Chairman: DR R. A. S. LAWSON

Age differences in the response to LH-RH treatment in male lambs. D. B. Galloway, Y. Cotta, J. Pelletier and M. Terqui, School of Veterinary Science, University of Melbourne, Werribee, Vic. 3030, Australia, and I.N.R.A., Station de Physiologie de la Reproduction 33780, Nouzilly, France.

Patterns of LH, FSH and testosterone levels in the developing ram. V. W. K. Lee, I. A. Gumming, D. M. de Kretser, J. K. Findlay, B. Hudson and E. J. KEOGH, Medical Research Centre, Prince Henry's Hospital, Melbourne 3004, and Department of Agriculture, Victoria, Reproduction Research Station, University of Melbourne, Howard Florey Institute of Experimental Physiology and Medicine, Melbourne, 3052, Australia. 
In contrast to the rat, sheep have a better defined prepubertal period and the present study was undertaken to define the patterns of LH, FSH and testosterone secretion in the developing ram. Testicular biopsies were made at various stages of development to provide assessment of sexual maturation.

Male crossbred Merino-Corriedale lambs were bled at weekly intervals for the first 4 weeks of postnatal life and then at 2-week intervals. On each occasion, three samples of $10 \mathrm{ml}$ of blood at 20-min intervals were taken from the jugular vein of each ram lamb and the plasma samples collected were analysed for LH, FSH and testosterone content by radioimmunoassay.

Of eleven ram lambs, five were bled for a period of 45 weeks after birth and the remaining animals for periods of up to 17 postnatal weeks. In both groups, plasma FSH levels were low (15 to $25 \mathrm{ng} / \mathrm{ml}$ ) at birth, but were seen to increase by the 4th postnatal week, reaching peak levels of 40 to $50 \mathrm{ng} / \mathrm{ml}$ between 5 and 6 weeks of age. Thereafter, a slight decline in FSH levels was observed followed by marked variations ( 25 to $35 \mathrm{ng} / \mathrm{ml}$ ) for the next 30 weeks. FSH levels were greater than $35 \mathrm{ng} / \mathrm{ml}$ between 37 and 45 weeks of age at a time when mature spermatozoa were first seen in the germinal epithelium.

Similarly, LH levels were low at birth $(<0.5 \mathrm{ng} / \mathrm{ml})$ and were elevated to peak levels of 2 to $3 \mathrm{ng} / \mathrm{ml}$ by the 5 th postnatal week. Shortly thereafter, fluctuations between 1 and $2 \mathrm{ng} / \mathrm{ml}$ occurred for the next 30 weeks. A gradual rise in $\mathrm{LH}$ concentrations was then observed and this rise occurred for the next 8 weeks, reaching levels of 3 to $3.5 \mathrm{ng} / \mathrm{ml}$. An apparent decline in $\mathrm{LH}$ concentrations to those seen in adult rams was then observed during the next 3 weeks. Preliminary data on testosterone show that there was no significant change in relation to the early gonadotrophin peak but rather a steady, slow rise up to 33 weeks followed by a sharp increase simultaneous with the achievement of peak LH levels between 36 and 41 weeks.

Histological examination of the testis in these ram lambs revealed that sexual maturation did not occur until 39 to 42 weeks of postnatal life. The earliest germinal cell changes seen were those of Sertoli cell maturation which occurred between 13 and 24 weeks after birth. There was no good correlation between FSH levels and histology and the reason for the peaks of LH and FSH seen at 5 to 6 weeks of age is unknown. These peaks may be similar to those seen in the rat at birth (Lee, de Kretser, Hudson \& Wang, 1974) and may be due to a cessation of inhibitory influences from the neonatal testes.

\section{REFERENGE}

Lee, V. W. K., de Kretser, D. M., Hudson, B. \& WANG, G. (1974) F. Reprod. Fert. 36, 479 480.

Plasma LH patterns in cryptorchid rams and wethers. M. A. HiLlARD and B. M. Bindon, Department of Physiology, University of New England, Armidale, N.S.W. 2351, and G.S.I.R.O., Division of Animal Genetics, P.O. Box 90, Epping, N.S.W. 2121, Australia.

Cryptorchidism is a condition of considerable clinical interest and, in theory, should provide a model for study of some aspects of the hypothalamus- 
pituitary-testis axis. The present study was carried out to determine the plasma LH fluctuations in normal, unilaterally cryptorchid, bilaterally cryptorchid and castrated rams.

The animals used were drawn from three flocks. Rams in which bilateral cryptorchidism had been surgically induced at 24 to 31 days of age, their twins, castrated at the same age, and normal rams, were from a Corriedale flock (Flock 1). Unilaterally cryptorchid and normal rams were drawn from a pure Merino line (Flock 2). A small inbred line of animals developed from polled Merinos, partly described by Claxton \& Yeates (1972), provided intact and natural bilaterally cryptorchid rams (Flock 3 ). All animals were 3 to 4 years of age at the time of the study.

Plasma LH was measured by radioimmunoassay in jugular venous samples taken at 30-min intervals from 09.00 hours. Eleven or twelve sequential samples were taken from each animal by venepuncture.

Table 1 presents the overall mean LH (ng NIH-LH-S16/ml) values for the various subgroups from Flocks 1 to 3.

Table 1. Mean plasma LH (ng NIH-LH$\mathrm{S} 16 / \mathrm{ml}$ ) in cryptorchid and castrated rams

\begin{tabular}{cccc}
\hline Flock & Intact rams & Cryptorchid rams & Wethers \\
\hline 1 & $1.52 \pm 0.26$ & $10.91 \pm 4 \cdot 41$ & $30.21 \pm 3.87$ \\
& $(0.1$ to 3.8$)$ & $(0.7$ to 41.5$)$ & $(2 \cdot 7$ to $61 \cdot 3)$ \\
2 & $0.96 \pm 0.21$ & $0.82 \pm 0.25$ & \\
& $(0.0$ to 4.0$)$ & $(0.1$ to 3.2$)$ & \\
3 & $1.75 \pm 0.44$ & $13.36 \pm 2 \cdot 45$ & \\
& $(0.2$ to $22 \cdot 6)$ & $(1.0$ to $24 \cdot 3)$ & \\
\hline
\end{tabular}

Range in parentheses.

Episodic $\mathrm{LH}$ release (i.e. peaks of $\mathrm{LH}>5 \mathrm{ng} / \mathrm{ml}$ ) was evident in $0 / 6,5 / 6$ and $6 / 6$ of the intact, bilaterally cryptorchid and castrated rams, respectively, in Flock $1 ; 0 / 5$ and $0 / 2$ of the intact and unilaterally cryptorchid rams in Flock 2, and $2 / 5$ of the rams and $5 / 5$ of the bilaterally cryptorchid rams in Flock 3.

These data indicate that, with the exception of Flock 1 rams, normal and unilaterally cryptorchid rams showed no evidence of LH peaks; castration was followed by elevated LH levels, confirming previous work (Reeves, Arimura \& Schally, 1970); and LH patterns in the cryptorchid rams were between these two extremes. Finally, the results indicate that cryptorchidism is a condition which will provide an experimental model suitable for studies of the hypothalamus-pituitary-testis axis in the absence of spermatogenesis.

\section{REFERENGES}

Claxton, J. H. \& Yeates, N. T. M. (1972) F. Hered. 63, 141-144.

Reeves, J. J., Arimura, A. \& Schally, A. V. (1970) J. Anim. Sci. 31, 933-936. 
Effect of $\alpha$-chlorohydrin on the fertility of rams and on the metabolism of spermatozoa in vitro. P. D. G. Brown-Woodman, I. G. White and S. Salamon, Departments of Veterinary Physiology and Animal Husbandry, University of Sydney, N.S.W. 2006, Australia.

Alpha-chlorohydrin is an antifertility drug which appears to act on the epididymis-perhaps the most promising site for blocking fertility in the male. The present study was undertaken to investigate the fertility of rams before, during and 1 month after injection of $\alpha$-chlorohydrin; the work was also designed to determine whether the onset of infertility can be correlated with any derangement of metabolism of the spermatozoa or changes in the epididymal environment.

Ten ewes were inseminated with semen $(0.1 \mathrm{ml})$ from each of five rams. A dose of $25 \mathrm{mg} \alpha$-chlorohydrin/ $\mathrm{kg}$ was injected intramuscularly daily for 3 days into each ram. Ten more ewes were inseminated with the semen from the same ram on Day 3 of injections and a further ten with semen collected 1 month after the last injection. Ewes were checked 32 days after insemination for return to service and at 160 days for evidence of lambing. Lambing following insemination with semen of rams prior to injection was $36 \%$, during injection $6 \%$, and 30 days after injection $94 \%$. The fertility of semen before injection was low because of the unavoidable use of the first ewes of the flock to come into oestrus. The reduced fertility after injection of rams with $\alpha$-chlorohydrin appears to coincide with the decreased respiratory and glycolytic activity of the spermatozoa and was fully reversible.

The antifertility effect of $\alpha$-chlorohydrin could be directly on the spermatozoa or caused by dysfunction of the epididymis. A study was therefore carried out to determine whether the epididymal environment is necessary for the detrimental effect of $\alpha$-chlorohydrin on ram spermatozoa. The effect of $\alpha$-chlorohydrin on rabbit spermatozoa in vitro was also studied in view of reports that its administration does not affect the fertility of the spermatozoa.

Washed spermatozoa were incubated with glucose $(5 \mathrm{~mm})$ and $\alpha$-chlorohydrin $(0,0.01,0.1,1.0$ and $10.0 \mathrm{mg} / \mathrm{ml})$ and respiratory and glycolytic activity of the spermatozoa were measured. The metabolism of ram spermatozoa was reduced at each $\alpha$-chlorohydrin concentration and, even at 0.01 $\mathrm{mg} / \mathrm{ml}$, oxygen uptake was almost halved. At $10 \mathrm{mg} \alpha$-chlorohydrin $/ \mathrm{ml}$, the oxygen uptake of ram spermatozoa was inhibited by $83 \%$ whereas the oxygen uptake of rabbit spermatozoa was inhibited by only $24 \%$.

The results indicate that $\alpha$-chlorohydrin has a direct and marked detrimental effect on the metabolic activity of ram spermatozoa and it would appear that neither the epididymis nor its secretions are necessary for the inhibition. While rabbit spermatozoa are affected by $\alpha$-chlorohydrin, a much greater concentration is required and, even then, the result is not so dramatic. These results support the hypothesis that the primary action of $\alpha$-chlorohydrin is on the energy metabolism of spermatozoa in the cauda epididymidis.

It seems that the primary action of $\alpha$-chlorohydrin is inhibition of glycolysis, which results in a decreased respiratory rate. 
The molecular site of action of the anti-fertility agent, $\alpha$-chlorohydrin, in ram spermatozoa. D. A. I. SUTER, P. D. C. Brown-Woodman, H. MoHri and I. G. WhIte, Department of Veterinary Physiology, University of Sydney, N.S.W. 2006, Australia.

Previous work in this laboratory has shown that $\alpha$-chlorohydrin inhibits the respiration and glycolysis of washed ram spermatozoa in vitro. In the present study, an attempt has been made to define the respiratory and/or glycolytic reaction step(s) inhibited by $\alpha$-chlorohydrin in vitro.

The respiratory and glycolytic metabolism of added $\left[\mathrm{U}-{ }^{14} \mathrm{C}\right]$ fructose $(5 \mathrm{~mm})$, lactate (5 mM), glycerol (5 mM), dihydroxyacetone phosphate (5 mM), dihydroxyacetone $(10 \mathrm{~mm}), \alpha$-glycerophosphate $(10 \mathrm{mM})$ and of endogenous substrates by washed ram spermatozoa has been followed during incubation for $3 \mathrm{hr}$ in the presence of $0.01,0.1,1.0$ or $10.0 \mathrm{mg} \alpha$-chlorohydrin $/ \mathrm{ml}$. A dose of $0.01 \mathrm{mg} \alpha$-chlorohydrin/ml significantly inhibited the oxygen uptake of spermatozoa incubated with $\left[\mathrm{U}-{ }^{14} \mathrm{C}\right]$ fructose by $47 \%$. This inhibition was increased to $70 \%$ after incubation with $\alpha$-chlorohydrin $(\geqslant 0.1 \mathrm{mg} / \mathrm{ml})$, while the appearance of radioactivity in the $\mathrm{CO}_{2}$ was almost completely eliminated. The uptake of fructose was decreased by at least two-thirds and lactate production totally suppressed whenever $\alpha$-chlorohydrin was present. By contrast, respiration of spermatozoa incubated with dihydroxyacetone phosphate, dihydroxyacetone and $\alpha$-glycerophosphate was little affected after the addition of $0.1 \mathrm{mg}$ $\alpha$-chlorohydrin $/ \mathrm{ml}(20 \%$ inhibition), while $10 \mathrm{mg} / \mathrm{ml}$ of the inhibitor was required to inhibit the oxygen uptake by an amount similar to that found with fructose $(70 \%)$. Incubation of spermatozoa with glycerol or lactate required $\alpha$-chlorohydrin at a concentration of $1.0 \mathrm{mg} / \mathrm{ml}$ to produce significant inhibition of respiration, whereas endogenous respiration was little affected even at $10 \mathrm{mg} / \mathrm{ml}$ of the inhibitor. These results strongly suggest that $\alpha$-chlorohydrin, initially at least, inhibits an enzyme reaction in the glycolytic pathway and that this site is subsequent to the formation and/or entry of the triose-phosphates into the pathway.

The oxygen consumption of ram sperm mid-pieces (essentially mitochondria) prepared by the method of Mohri, Mohri \& Ernster (1965) and incubated with either $\alpha$-glycerophosphate $(20 \mathrm{~mm})$, succinate $(20 \mathrm{~mm})$ or pyruvate $(20 \mathrm{~mm})+$ malate $(20 \mathrm{mM})$ was not significantly affected by the addition of $\alpha$-chlorohydrin at concentrations up to $10 \mathrm{mg} / \mathrm{ml}$. This provides further confirmatory evidence that the initial site of inhibition by $\alpha$-chlorohydrin is in the glycolytic rather than subsequent oxidative pathways.

The direct effect of $\alpha$-chlorohydrin on a number of the glycolytic and closely related enzymes of ram spermatozoa has been investigated in tissue extracts prepared by sonication and assayed by standard spectrophotometric procedures. At this time no direct inhibitory effect of $\alpha$-chlorohydrin has been found on hexokinase, phosphofructokinase, glycerokinase, $\alpha$-glycerophosphate dehydroxygenase, triose-phosphate isomerase, glyceraldehyde-3-phosphate dehydrogenase, pyruvate kinase or lactate dehydrogenase.

It is probable that $\alpha$-chlorohydrin does not act by direct inhibition of one of the glycolytic enzymes. However, measurement of glycolytic intermediates and 
enzyme activities in ram spermatozoa following incubation with fructose and $\alpha$-chlorohydrin indicates indirect inhibition of glyceraldehyde-3-phosphate dehydrogenase.

\section{REFERENGE}

Mohri, H., Mohri, T. \& Ernster, L. (1965) Expl Cell Res. 38, 217-246.

\section{Cholesterol and phospholipid content of mammalian spermatozoa and its relation to membrane structure and cold-shock. ANNABELLE DARIN- BennetT and I. G. White, Department of Veterinary Physiology, The University of Sydney, N.S.W. 2006, Australia.}

The structure and organization of membranes is partly determined by the nature of the component lipids. Polyunsaturated fatty acids tend to form expanded films which are condensed in the presence of cholesterol (Chapman \& Wallach, 1968). In view of the highly unsaturated nature of mammalian sperm phospholipids (Poulos, Darin-Bennett \& White, 1973), the cholesterol content may be important in forming a reasonably impermeable and cohesive membrane structure, able to withstand environmental stress. It was therefore decided to determine the amount of cholesterol present in mammalian spermatozoa. Four species were chosen, the ram, bull, rabbit and man. The first two possess spermatozoa with a high degree of unsaturation in their phospholipids, whereas the spermatozoa of the other two species have approximately equal levels of polyunsaturated and saturated fatty acids (Poulos et al., 1973).

Ram semen was collected by electroejaculation, bull and rabbit semen with an artificial vagina and human semen by massage. The cholesterol and phospholipid content was estimated in lipid extracts prepared from the spermatozoa as described by Poulos et al. (1973). Cholesterol was measured using o-phthalaldehyde reagent.

A minimum of three analyses were undertaken for each species, each sample consisting of two to four pooled ejaculates. Rabbit and human spermatozoa contained 545 and $555 \mu \mathrm{g}$ cholesterol $/ 10^{9}$ cells, respectively, which was approximately twice the amount present in $\mathrm{ram}\left(266 \mu \mathrm{g} / 10^{9} \mathrm{cells}\right)$ and bull spermatozoa $\left(300 \mu \mathrm{g} / 10^{9}\right.$ cells). The cholesterol content within each group was similar and this was reflected in the molar ratio of phospholipid:cholesterol which was approximately 0.4 for ram and bull spermatozoa and approximately 1.0 for human and rabbit spermatozoa.

The higher cholesterol content, together with the lesser degree of unsaturation of rabbit and human spermatozoa phospholipids would suggest a more compact and possibly a less permeable and less easily disrupted membrane structure than exists in ram and bull spermatozoa. This may well influence such membrane properties as the ability to withstand disruptive external forces, such as cold-shock. It is significant that the spermatozoa with the higher cholesterol level and lesser degree of unsaturation in the phospholipids and therefore presumably the more compact membrane structure should also be more resistant to cold-chock (White \& Wales, 1960). The spermatozoa of the four species examined tend to 'group' in terms of cholesterol content in a 
similar manner with respect to polyunsaturated:saturated fatty acid ratio (Poulos et al., 1973). Therefore a distinct relationship seems to exist between the composition of the sperm membrane lipids so far determined and the physiological response of the membrane to stress.

\title{
REFERENGES
}

Chapman, D. \& Wallach, D. F. H. (1968) In Biological Membranes, pp. 125-202. Ed. D. Chapman. Academic Press, London.

Poulos, A., Darin-Bennetr, A. \& White, I. G. (1973) Comp. Biochem. Physiol. 46, 541-549.

WhIte, I. G. \& Wales, R. G. (1960) Int. F. Fert. 5, 195-201.

The effect of antispermatozoal antibodies on human spermatozoa in an in-vitro cervical mucus penetration test. R. PRICE and B. BOETTCHER, Department of Biological Sciences, The University of Newcastle, New South Wales 2308, Australia.

\author{
Session 4 \\ Ova AND IMPLANTATION \\ Chairman: DR N. MOORE
}

\section{Guest Legture}

Investigations in early mammalian development at the Marshal Laboratory, Cambridge. C. R. Austin, Physiological Laboratory, University of Cambridge, Cambridge CB2 3EG, England.

Superovulation and surgical collection of ova from cows on each of two successive cycles. Wendy Miller, L. H. Larsen, C. D. Nancarrow and R. I. Cox, Department of Veterinary Surgery, University of Sydney, and C.S.I.R.O., Division of Animal Physiology, Prospect, N.S.W. 2148, Australia.

Substantial superovulation responses have been obtained in cows following the second of two PMSG treatments during successive oestrous cycles, but this ovarian response diminished if there were longer intervals between treatments. This may be explained by the presence of serum antigonadotrophins (Jainudeen, Hafez, Gollnick \& Moustafa, 1966). We are investigating superovulation at two stages of the cycle, while using a prostaglandin analogue (I.C.I. 80,996) to induce luteolysis following PMSG treatment.

Responses to an injection of 2500 i.u. PMSG (Folligon: Organon Laboratories Ltd) given to fourteen mature, Hereford cows on Day 10 or 16 were compared to those to a similar treatment during the subsequent cycle. Either 24 or $48 \mathrm{hr}$ following PMSG, $800 \mu \mathrm{g}$ I.C.I. 80,996 were injected subcutaneously. Progesterone concentrations were assayed in plasma sampled on Day 10 or 16, on the day of prostaglandin injection and $24 \mathrm{hr}$ later, and on Days 2 and 5 following the treatment oestrus. The cows underwent midline laparotomy under general anaesthesia on Day 6 and ova were collected via a glass tube inserted into the uterus $5 \mathrm{~cm}$ from the utero-tubal junction. The uterine horns were flushed with sterile TCM 199. 
During the first treatment, four cows receiving PMSG $24 \mathrm{hr}$ before injection of prostaglandin were in oestrus within $36 \mathrm{hr}$, while the ten animals treated $48 \mathrm{hr}$ apart showed oestrus $50.8 \mathrm{hr}$ (mean) following prostaglandin. The time to onset of oestrus during the second treatment was between 36 and $120 \mathrm{hr}$. Six animals treated on Day 10 showed an ovulation rate of $5.3 \pm 3 \cdot 2$ (mean \pm S.D.) with $3.2 \pm 1.9$ fertilized ova collected ( $59 \%$ ), while eight animals treated on Day 16 had an ovulation rate of $7 \cdot 5 \pm 10 \cdot 6$ with $4 \cdot 0 \pm 5 \cdot 6$ fertilized ova collected $(53 \%)$. Following the second treatment on Day 16, four cows had a mean ovulation rate of $8 \cdot 8 \pm 3.6$ with $5 \cdot 5 \pm 4 \cdot 8$ ova collected $(63 \%)$, but only $18 \%$ of these were fertilized. Marked improvement of ovulation rate was observed in all but one animal.

Only a third of the animals receiving the second treatment on Day 10 ovulated, the rate being 14 compared with 6 from the first treatment. Of seven ova collected, three were fertilized $(43 \%)$. Mean plasma progesterone concentrations for cows first treated on Day 10 or 16 were 9.5 and $5.8 \mathrm{ng} / \mathrm{ml}$, on the day of prostaglandin injection 13.5 and $7.9 \mathrm{ng} / \mathrm{ml}$ and $24 \mathrm{hr}$ later 2.7 and $2.0 \mathrm{ng} / \mathrm{ml}$, respectively. The four animals having ovulation rates $>8$ had high ( $>32 \mathrm{ng} / \mathrm{ml}$ ) plasma progesterone concentrations on Day 10 or 16 following first treatment oestrus. Oestradiol-17 $\beta$ concentrations in peripheral plasma were high (up to $100 \mathrm{pg} / \mathrm{ml}$ ) at pro-oestrus for cows ovulating many eggs. Of seven animals treated for the second time, six responded to prostaglandin.

To date, it would appear that in animals responding poorly ( $<3$ ovulations) to PMSG treatment, a substantial increase in ovulation rate can be obtained when treatment is repeated on the next cycle. The uterine route of ova collection, while presenting some difficulties has led to no significant surgical adhesions as observed at the second operation. Handling of the ovaries and associated structures has been completely avoided except to observe ovulation rate, thus avoiding the risk of fimbrial adhesion to the ovary.

\section{REFERENGE}

Jainudeen, M. R., Hafez, E. S. E., Collnick, F. D. \& Moustafa, L. A. (1966) Am. F. vet.Res. 27,669675.

The effects of age and ovulation rate on egg transport in ewes. $L$. $P$. Gahill, R. A. S. Lawson and J. K. Findlay, ${ }^{*}$ Department of Agriculture and *University of Melbourne, S.S. Cameron Laboratory, Werribee, Victoria 3030, Australia.

The survival rate of eggs following homologous egg transfer at various times after oestrus in the ewe. I. D. Kill.een, Agricultural Research Station, Leeton, N.S.W. 2705, Australia.

\section{Session 5 \\ OVA AND IMPLANTATION \\ Chairman: DR G. R. AUSTIN}

The survival of embryos transferred asynchronously to ewes treated with progesterone. R. A. S. Lawson and L. P. CAHILl, Department of Agriculture, Victoria, S.S. Cameron Laboratory, Werribee, Victoria 3030, Australia. 
Progesterone requirements for the maintenance of pregnancy in the ovariectomized ewe. N. W. MOORE, Department of Animal Husbandry, University of Sydney Farms, Camden 2570, Australia.

It has been shown in this and other laboratories that progesterone alone will maintain pregnancy in ewes ovariectomized within a few days after oestrus. In the present experiment, these studies were extended to examine progesterone requirements in more detail.

Ewes which had been ovariectomized several months prior to the experiment were used and oestrus was induced in them by $35 \mu \mathrm{g}$ oestradiol-17 $\beta$ given by subcutaneous injection after a period of progesterone treatment $(5 \mathrm{mg}$ twice daily by intramuscular injection for 12 days). Progesterone treatment recommenced on the first day (Day 1) after oestrus and two regimens were used (Table 1).

Table 1. Progesterone treatment (mg) after oestrus

\begin{tabular}{|c|c|c|c|c|c|c|c|c|c|c|c|c|c|}
\hline \multirow{3}{*}{$\begin{array}{l}\text { Progesterone } \\
\text { regimen }\end{array}$} & \multicolumn{13}{|c|}{ Days after oestrus } \\
\hline & \multicolumn{2}{|c|}{1} & \multicolumn{2}{|c|}{2} & \multicolumn{2}{|c|}{3} & \multicolumn{2}{|c|}{4} & \multicolumn{2}{|c|}{5} & \multicolumn{2}{|c|}{6} & \multirow{2}{*}{$\begin{array}{l}7 \text { to } 24 \\
\text { a.m. }\end{array}$} \\
\hline & $a . m$. & p.m. & a.m. & p.m. & a.m. & p.m. & a.m. & p.m. & a.m. & p.m. & $a . m$. & p.m. & \\
\hline $\begin{array}{l}\text { Low } \\
\text { High }\end{array}$ & $\begin{array}{l}0.5 \\
1.0\end{array}$ & $\begin{array}{l}0.625 \\
1.25\end{array}$ & $\begin{array}{l}0.75 \\
1.5\end{array}$ & $\begin{array}{l}1 \cdot 0 \\
2 \cdot 0\end{array}$ & $\begin{array}{l}1.25 \\
2.5\end{array}$ & $\begin{array}{l}1.5 \\
3.0\end{array}$ & $\begin{array}{l}2 \cdot 0 \\
4 \cdot 0\end{array}$ & $\begin{array}{l}2 \cdot 5 \\
5 \cdot 0\end{array}$ & $\begin{array}{l}3 \cdot 0 \\
6 \cdot 0\end{array}$ & $\begin{array}{l}4.0 \\
8.0\end{array}$ & $\begin{array}{l}5 \cdot 0 \\
8 \cdot 0\end{array}$ & $\begin{array}{l}6 \cdot 0 \\
8 \cdot 0\end{array}$ & $\begin{array}{l}12 \cdot 0 \\
12 \cdot 0\end{array}$ \\
\hline
\end{tabular}

Fertilized eggs collected from donor ewes on Day 4 after oestrus were transferred to the uteri of ovariectomized ewes on Day $2 \frac{1}{2}, 4$ or $5 \frac{1}{2}$ after the induced oestrus. Transfers were made to 101 ewes and each received one egg. Progesterone treatment continued to the time of autopsy on Day 24 or 25.

At autopsy, normal embryos were recovered from forty-five ewes (Table 2).

In ewes on the low dose regimen there was a quadratic effect of age of tract at the time of transfer with maximum survival rates occurring following the synchronous transfer of Day-4 eggs to Day-4 uteri, whilst in ewes on the high regimen there was a linear effect of age of uterus with maximum survival following the asynchronous transfers of Day- 4 eggs to Day- $2 \frac{1}{2}$ uteri.

Table 2. Proportion of ovariectomized ewes with normal embryos at autopsy

\begin{tabular}{crr}
\hline \multirow{2}{*}{$\begin{array}{c}\text { Age of uterus at transfer } \\
\text { (days after oestrus) }\end{array}$} & \multicolumn{2}{c}{ Progesterone regimen } \\
\cline { 2 - 3 } & Low & High \\
\hline $2 \frac{1}{2}$ & $6 / 17$ & $13 / 16$ \\
4 & $12 / 17$ & $7 / 17$ \\
5 & $5 / 17$ & $2 / 17$ \\
\hline
\end{tabular}

All ewes received Day-4 eggs.

Clearly, the establishment of a uterine environment suitable for the survival and development of embryos was not simply dependent upon the duration of 
progesterone treatment. The dose regimens used did modify the duration of treatment required to develop a suitable environment. The procedures used in the experiment might be profitably used to study changes in the uterine environment associated with the failure, and the success, of embryo survival and development.

Initiation of implantation in the mouse with anterior pituitary hormones. A. A. Gidley-BAIRD and C. W. Emmens, Department of Veterinary Physiology, University of Sydney, N.S.W. 2006, Australia.

A series of replacement therapy experiments was carried out in hypophysectomized mice to determine which hormones of the anterior pituitary gland could initiate implantation.

The hormones tested were prolactin (NIH-P-B3; NIH-P-S9 and NIAMDRP-1); LH (NIH-LH-SI6); FSH (NIAMD-RAT FSH B-1) and growth hormone (NIH-GH-B-17). Virgin females of the $Q$ strain mouse were hypophysectomized between 34 and $36 \mathrm{hr}$ post coitum (p.c.). Coitus is taken as occurring at $0 \mathrm{hr}$ on the day of discovery of a copulatory plug (Day 1). Injection of protein hormones in $0.1 \mathrm{ml}$ of a $15 \%$ gelatin solution was started at $36 \mathrm{hr}$ p.c. Three further injections of the same hormones were given at $12-\mathrm{hr}$ intervals. At $84 \mathrm{hr}$ p.c., all animals received $1 \mathrm{mg}$ progesterone in $0.1 \mathrm{ml}$ of sesame oil. This dose of progesterone was repeated at 108, 132 and $156 \mathrm{hr}$ and the animals were killed and examined at $166 \mathrm{hr}$ p.c. At the start of the injection schedule there were ten animals in each group. The results were as follows. (1) No hormone in doses up to $50 \mu \mathrm{g} /$ injection could by itself initiate implantation. (2) No combinations of prolactin, $\mathrm{LH}$ and $\mathrm{GH}$ stimulated implantation. (3) Combinations of prolactin with FSH, $\mathrm{LH}$ with FSH and prolactin with $\mathrm{LH}$ and FSH were successful to various degrees in initiating implantation (for dosage levels see Table 1). (4) Equal success in initiating implantation was achieved with $50 \mu \mathrm{g}$ bovine, ovine or rat prolactin in combination with $50 \mu \mathrm{g}$ FSH. (5) Growth hormone had no significant effect in any situation in increasing implantation numbers or weight.

Table 1. Initiation of implantation in hypophysectomized mice with prolactin, LH and FSH

\begin{tabular}{|c|c|c|c|c|c|c|}
\hline \multicolumn{3}{|c|}{ Dose/injection $(\mu g)$} & \multirow{2}{*}{$\begin{array}{c}\text { No. of } \\
\text { animals } \\
\text { injected }\end{array}$} & \multirow{2}{*}{$\begin{array}{l}\text { No. of } \\
\text { animals with } \\
\text { implantations }\end{array}$} & \multirow{2}{*}{$\begin{array}{c}\text { No. of } \\
\text { animals with } \\
\text { blastocysts }\end{array}$} & \multirow{2}{*}{$\begin{array}{c}\text { Animals with } \\
\text { implantations }(\%)\end{array}$} \\
\hline Prolactin & FSH & $L H$ & & & & \\
\hline Bovine 50 & 50 & - & 8 & 8 & 0 & 100 \\
\hline Bovine 50 & 10 & - & 7 & 3 & 4 & 43 \\
\hline Bovine 50 & 10 & 10 & 9 & 6 & 2 & 75 \\
\hline Bovine 50 & 5 & 5 & 7 & 0 & 7 & 0 \\
\hline & 50 & 50 & 8 & 4 & 4 & 50 \\
\hline- & 10 & 50 & 8 & $3 *$ & $6^{*}$ & 37 \\
\hline 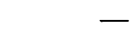 & 50 & 10 & 8 & 6 & 2 & 75 \\
\hline- & 10 & 10 & 9 & 0 & $\overline{9}$ & 0 \\
\hline Ovine 50 & 50 & - & 8 & 8 & 0 & 100 \\
\hline Rat & 50 & - & 10 & 10 & 0 & 100 \\
\hline
\end{tabular}

* One animal had implantations in one horn and blastocysts in the other. 
It would appear that a combination of prolactin and FSH is all that is required for the initiation of implantation in the mouse. However, the results showing the capacity of LH and FSH together to initiate implantation suggest that LH may also play a rôle. The potential involvement of LH is supported by evidence from this laboratory of an increase in plasma levels of $\mathrm{LH}$ prior to implantation, and the capacity of an anti-LH serum to prevent implantation when given early in pregnancy. Prolactin from three different species was equally effective in combination with FSH, showing a lack of species specificity.

Activity of certain glycolytic enzymes in developing mouse embryos. P. QuinN and L. P. KozaK, Department of Biological Sciences, University of Nerecastle, N.S.W. 2308, Australia, and The Fackson Laboratory, Bar Harbor, Maine 04609, U.S.A.

It would appear that the rate of glycolysis in the preimplantation mouse embryo is more under the control of the ratio of ATP to ADP rather than changes in the absolute activity of glycolytic enzymes (Quinn \& Wales, 1973). Nevertheless, the activity of all glycolytic enzymes has not been measured in the preimplantation mouse embryo and thus the activities of certain of these enzymes were assayed to see if a change in their activity was responsible for the altered utilization of glucose as an energy source for development between the twoand eight-cell stage.

The activities of the following glycolytic enzymes were assayed at all stages of development in the preimplantation mouse embryo: triose phosphate isomerase (TPI), glyceraldehyde-3-phosphosphate dehydrogenase (G3PDH), phosphoglycerokinase (PGK), and phosphoglyceromutase (PGM). The assays were performed using standard spectrophotometric assays in microcuvettes.

The activities of TPI, G3PDH and PGM remained relatively constant from the one-cell to blastocyst stage. The activity of PGK decreased by approximately a half between the eight-cell and morula stage and remained constant thereafter. After the eight-cell stage, the ratio of the enzyme activities approached that found in adult tissues and was constant on an equimolar basis. This indicates that the expression of the activities of these enzymes is under coordinated control. The activity of PGK in one-cell ova of XX mice was double that in the ova of XO mice. A ratio of one was found for the other three enzymes in the ova of XX and XO mice. It would appear, therefore, that only the activity of PGK is under the control of the X-chromosome.

Since none of the enzymes showed any marked increase in activity between the two- and eight-cell stage, changes in enzyme activity per se cannot be the reason for the increase in glycolysis between these stages. The dramatic fall in the levels of activity of PGK between the eight-cell and morula stage raises the question as to when X-inactivation occurs in the mammalian embryo. If $\mathrm{X}$-inactivation had occurred between these stages, a less marked decrease in activity would have been expected. The levels of PGK measured reflect a balance between the synthesis and degradation of PGK which is thus confounded with the time of $\mathrm{X}$-chromosome inactivation. A bimodal distribution of PGK activity in individual Day-7 embryos (Day 1 = day of plug), which would 
be indicative of male and female embryos, did not occur, indicating that Xinactivation had already occurred by this stage. Therefore, $\mathrm{X}$-inactivation for PGK presumably occurs between Days 3 and 7 of development in the mouse.

\section{REFERENGE}

Quinn, P. \& Wales, R. G. (1973) F. Reprod. Fert. 35, 273-287.

The effect of exogenous substrate on the metabolism of glycogen during early development of the preimplantation mouse embryo. I. L. PIKe and R. G. WALES, Department of Veterinary Physiology, The University of Sydney, N.S.W. 2006, Australia.

Glycogen metabolism by the preimplantation mouse embryo has been studied previously by measuring the total glycogen content, the activity of the enzyme glycogen synthetase and the incorporation of isotopically labelled glucose into glycogen. The reported data contain some apparent anomalies in that total glycogen content and glycogen synthetase activity increase after the first cleavage division while the accumulation of glucose carbon into glycogen is not enhanced. At the blastocyst stage glycogen synthetase activity decreases markedly but glucose incorporated into glycogen increases. Further studies have been initiated to examine the effect of exogenous substrate on the metabolism of glycogen during preimplantation development.

Embryos from the one-cell stage to the late blastocyst were cultured for $24 \mathrm{hr}$ in medium containing $\left[\mathrm{U}^{14} \mathrm{C}\right]$ glucose at concentrations of either $5.56 \mathrm{~mm}$ or $0.28 \mathrm{~mm}$ (sp. act. $3 \mu \mathrm{Ci} / \mu \mathrm{mol}$ and $28 \mu \mathrm{Ci} / \mu \mathrm{mol}$, respectively). At stages prior to the third cleavage division, the culture medium was supplemented with $5 \mathrm{~mm}$ lactate and $0.5 \mathrm{~mm}$ pyruvate to provide energy substrates essential for continued development. At later stages experiments were conducted with and without the addition of these supplementary substrates. Pulse/chase studies were also used to determine glycogen synthesis and breakdown by morulae. Glycogen was extracted from the acid-soluble portion of the embryos by ethanol precipitation and further characterized by amylase digestion, ionexchange chromatography and paper chromatography of an acid hydrolysate.

Before the eight-cell stage of development the incorporation of glucose into glycogen accounted for less than $10 \%$ of the acid-soluble label accumulated within the embryo. Although the total glycogen content of the mouse embryo increases by $1.3 \mathrm{ng}$ between the one- and two-cell stages of development; one-cell embryos accumulated only $0.14 \mathrm{pg}$ atoms of glucose in their glycogen stores during $24 \mathrm{hr}$ in culture in the present study. This is equivalent to an incorporation of $3.7 \mathrm{pg}$ glucose and suggests that exogenous glucose is not a significant precursor of the glycogen energy pool during early cleavage.

There was a highly significant (thirty-fold) increase in the label found in glycogen between the eight-cell and morula stages while the concomitant rise in other labelled acid-soluble compounds was three-fold. The addition of lactate and pyruvate to the culture medium greatly enhanced the synthesis of glycogen from glucose. Thus in eight-celled embryos the amount of glucose carbon incorporated into glycogen increased from 2.3 to $9.2 \mathrm{pg}$ atoms/embryo 
when lactate and pyruvate were added to the medium. At the morula stage their addition increased glucose incorporation from 77.7 to $171.9 \mathrm{pg}$ atoms/ embryo. The rate of glycogen synthesis remained high at implantation and represented $38 \%$ of the total label incorporated.

Glucose carbon was rapidly accumulated in glycogen during pulse culture and the level of label was not diminished during chase culture provided that a simple energy substrate was available. Little glycogen was detected in blastocysts which were chase cultured in medium lacking lactate, pyruvate and glucose. Thus glycogen synthesized by the embryo from glucose subunits after the third cleavage may not be mobilized in vivo unless the level of simple energy substrate within the uterine secretions becomes seriously depleted.

\section{Session 6}

\section{OVA AND IMPLANTATION}

\section{Chairman: DR I. A. CUMMING}

Effect of human uterine rinsings on oxygen consumption and motility of spermatozoa. Suzanne R. Morris, I. G. White and W. R. Jones, Departments of Veterinary Physiology, and Obstetrics and Gynaecology, University of Sydney, N.S.W. 2006, Australia.

The influence of fluid from the female genital tract on the metabolism of spermatozoa has received increased attention in recent years. In some species (e.g. rabbit and sheep), a stimulation of sperm respiration occurs during incubation in vitro with uterine or tubal fluids, or following incubation in the female reproductive tract (Hamner \& Williams, 1963; Murdoch \& White, 1967; Black, Crowley, Duby \& Spilman, 1968).

Similar investigations are reported here using fluid obtained from the uteri of women by rinsing the endometrium in situ with isotonic saline from a micro-urine collecting tube inserted through the cervix. After centrifuging the uterine washings, aliquots were incubated at $37^{\circ} \mathrm{C}$ with human spermatozoa under two conditions, (a) washed spermatozoa in Krebs--Ringer phosphate buffer, $\mathrm{pH} 7.2$ to 7.4 (KRP), with no added substrate and (b) semen diluted in KRP with added glucose. Controls containing isotonic saline instead of uterine fluid were incubated simultaneously and the oxygen consumption of the spermatozoa was determined by polarographic measurements of oxygen tension. A decrease in the oxygen consumption was found in the presence of uterine rinsings when compared to the control and this effect occurred with and without added glucose as substrate. The magnitude of the decrease in oxygen consumption was very variable, ranging from $8 \%$ to over $80 \%$ of the control. There was no apparent correlation between the magnitude of the decrease and the day of the menstrual cycle on which rinsings were collected. The protein concentration of the rinsings was determined and corrected for contaminating blood plasma protein but again no correlation could be found between this value and the degree of inhibition of sperm respiration. 
The effect of the uterine rinsings on the motility of human spermatozoa has also been investigated. Washed spermatozoa and diluted semen containing glucose were incubated at $37^{\circ} \mathrm{C}$ in the presence of uterine rinsings with controls containing isotonic saline. The motility of the spermatozoa was checked every $30 \mathrm{~min}$ and scored as 0 to 10 . The control spermatozoa remained highly motile for up to $4 \mathrm{hr}$. In the presence of uterine rinsings the spermatozoa were as motile as the controls for 60 to $90 \mathrm{~min}$, but then motility decreased significantly. This was evident by a decrease in the number of highly motile spermatozoa, rather than a general decrease in the motility of all spermatozoa. After $5 \mathrm{hr}$, at least half of the control spermatozoa were still motile while the spermatozoa exposed to uterine rinsings were almost completely immotile.

These experiments indicate that the uterine fluid of women contains a factor that inhibits the oxygen uptake and motility of spermatozoa. Thus the metabolic response of human spermatozoa to their uterine environment may be different from that of other species so far examined.

\section{REFERENGES}

Black, D. L., Growley, L. V., Duby, R. T. \& Spilman, G. H. (1968) F. Reprod. Fert. 15, 127-130.

Hamner, C. E. \& Williams, W. L. (1963) F. Reprod. Fert. 5, 143-150.

Murdoch, R. N. \& White, I. G. (1967) J. Reprod. Fert. 14, 213-223.

Relationship between cervical mucus spinbarkheit and the direction of sperm migration in ewes with clover disease. N. R. ADAMs, C.S.I.R.O., Division of Animal Health, Wembley, Western Australia 6014, Australia.

In ewes with permanent clover infertility, the main lesion appears to be an alteration in cervical mucus (Smith, 1971), which impedes cervical sperm transport. The nature of the changed cervical mucus is further described in this report.

Cervical mucus was collected from forty-one ewes, fifteen of which had previously run for 4 years on highly oestrogenic (Dinninup) subterranean clover, eleven on moderately oestrogenic (Daliak) subterranean clover, and fifteen on low oestrogenic (Northam A or Uniwager) subterranean clover. Ewes were not on oestrogenic pasture at the time of study. Mucus was collected once daily from ewes at natural oestrus, as detected by vasectomized, raddled rams. The spinbarkheit, the length that a thread of mucus can be drawn out, was determined, and the direction of sperm migration was observed by the method of Tampion \& Gibbons (1962). To simplify comparisons, 33 was subtracted from the percentage of spermatozoa heading along the axis of orientation of the mucus, the percentage heading across the axis was subtracted from 33, and the two resulting numbers added together to give an 'index of orientation'.

The mean ( \pm S.E.) spinbarkheit for the ewes on high, moderate and low oestrogenic pastures were: $28 \cdot 5 \pm 5 \cdot 4 ; 33 \cdot 3 \pm 7 \cdot 0$; and $72 \cdot 2 \pm 8 \cdot 7$. The corresponding sperm orientation indices were: $26 \cdot 4 \pm 4 \cdot 0 ; 36 \cdot 8 \pm 6 \cdot 5$; and $46 \cdot 5 \pm 4.7$. Within ewes, the spinbarkheit and the orientation of spermatozoa were correlated $(r=0.66, P<0.001)$. 
Since spinbarkheit reflects molecular structure, the results provide further evidence for the hypothesis that the structure of cervical mucus determines the orientation of sperm migration and thus the efficiency of sperm transport in the cervix. The results also suggest a means for diagnosing permanent clover infertility under flock conditions.

\section{REFERENCES}

Smirt, J. F. (1971) Aust. F. agric. Res. 22, 513-519.

Tampion, D. \& GibBons, R. A. (1962) Nature, Lond. 194, 381.

Sperm transport in ewes at oestrus following embryonic death. T. O'Shea, ${ }^{*}$ F. A. Pigott, $\dagger$ C. J. Thwaites $\dagger$ and T. N. Edey, $\dagger{ }^{*}$ Departments of Physiology and †Livestock Production, University of New England, Armidale, N.S.W. 2351, Australia.

Ovarian follicular blood flow in the sheep. N. W. BRUCE and R. M. Moor, The Nuffield Institute for Medical Research, Headley Way, Headington, Oxford OX3 9DS, England, and A.R.C. Unit of Reproductive Physiology and Biochemistry, 307 Huntingdon Road, Cambridge CB3 0JQ, England.

In Welsh Mountain sheep around ten viable follicles greater than $1 \mathrm{~mm}$ in diameter develop by Day 14 of the oestrous cycle. Generally only one of these follicles matures to finally ovulate. Radioactive microspheres were used to measure follicular blood flow and to determine whether changes in flow initiated or accompanied follicular maturation.

Table 1. Ovarian blood flow and peripheral plasma progesterone levels in sheep

\begin{tabular}{lccc}
\hline & \multicolumn{3}{c}{ Stage of oestrous cycle (day) } \\
\cline { 2 - 4 } & 14 & 15 & 16 \\
\hline No. of sheep & 8 & 6 & 10 \\
Peripheral plasma progesterone $(\mathrm{ng} / \mathrm{ml}) * *$ & $3 \cdot 3 \pm 0.5$ & $3 \cdot 2 \pm 0 \cdot 7$ & $0 \cdot 2 \pm 0 \cdot 06$ \\
Blood flow (ml min & -1 \\
CL $\left.100 \mathrm{~g}^{-1}\right)$ & $1122 \pm 169$ & $708 \pm 203$ & $116 \pm 19$ \\
Stroma & $157 \pm 23$ & $258 \pm 52$ & $176 \pm 24$ \\
Follicles* & $637 \pm 81$ & $742 \pm 102$ & $1096 \pm 147$ \\
\hline
\end{tabular}

* Variation significant, $P<0.05$.

** Variation significant, $P<0.01$.

Eight sheep at Day 14, six at Day 15 and ten at Day 16 of the oestrous cycle were examined. Each sheep was anaesthetized with Fluothane and catheters were inserted into the left ventricle for microsphere injection and the axillary artery and both femoral arteries for blood withdrawal, blood pressure and pulse rate measurements. About $1,000,000$ microspheres, $15 \pm 5 \mu \mathrm{m}$ in diameter and labelled with ${ }^{46} \mathrm{Sc}$, were injected into the ventricle over a $20-\mathrm{sec}$ period while blood was withdrawn at a steady rate of $40 \mathrm{ml} / \mathrm{min}$ to determine cardiac output and absolute rate of blood flow. The sheep was then killed and its ovaries were separated into luteal, stromal and follicular components. Each follicle was carefully dissected free from stromal tissue. Its diameter was 
measured and its weight estimated from a weight versus diameter chart previously prepared. It was classified as normal or atretic on the basis of a microscopic examination.

Ovarian follicles were found to receive a high rate of blood flow, per $\mathrm{g}$ of tissue, comparable with that found in the functional CL (Table 1). Follicular blood flow appeared to rise towards oestrus while luteal blood flow declined in parallel with peripheral plasma progesterone levels. However, on detailed analysis no difference in flow was observed between normal and atretic follicles. Furthermore, the larger follicles, including the one probably destined for ovulation, had significantly lower flow rates $(P<0.01)$ than the smaller follicles.

Follicular development and maturation did not appear to be related to gross changes in follicular blood flow. The significance of the remarkably high rates of follicular blood flow remains to be seen.

The fate of large 'cystic' ovarian follicles in sheep. A. J. MAcKENZIE and T. N. EDEY, Department of Livestock Production, University of New England, Armidale 2351, Australia.

The occurrence of large unruptured ovarian follicles coexistent with normally developing CL early in the oestrous cycle of the ewe has been observed on many occasions since the early report of Grant (1934). Their occurrence is apparently rare in normal cyclic sheep but common following over-stimulation by gonadotrophins. In the latter circumstances, luteinization, generally, but not exclusively without prior rupture, has been reported by several workers (e.g. Robinson, 1950). In unstimulated ewes, Moore, Rowson \& Short (1960) observed the apparent development of additional CL from large follicles coexistent with a recent CL in each ewe. Again, whether or not asynchronous ovulation had occurred is not known. This communication presents new information on the fate of large follicles in ewes which had received no exogenous gonadotrophins.

During the breeding season, oestrus and ovulation was studied in 113 mature Merino ewes which underwent various nutritional treatments. At laparotomies on Day 3 or 4 after the onset of oestrus (Day 0 ), nine ewes which already had at least one developing CL also had a large unruptured follicle on the same or the opposite ovary. Six ewes each had a follicle 10 to $15 \mathrm{~mm}$ diameter and three had a follicle 6 to $7 \mathrm{~mm}$ in diameter. Their occurrence was not related to the prior nutritional treatment of the ewes.

The fate of these follicles was observed by means of serial laparotomies at approximately 2-day intervals, thus providing a series of ovarian observations at Days 3 to 4,5 to 6,7 to 8 and 9 to 11 following the onset of oestrus. At each observation, the number, size and appearance of CL and follicles were recorded. At the final examination on Days 9 to 11 , the ovary bearing the large follicle was removed and prepared for histology.

Of the follicles which were initially of 10 to $15 \mathrm{~mm}$ diameter on Days 3 to 4 , five were thin-walled, apparently fragile, and with a clear area at the apex. At the second inspection (Days 5 to 6) they had increased in size to 12 to $20 \mathrm{~mm}$ diameter and were still taut and apparently fragile. At the Days 7 to 8 examin- 
ation the clear area on the follicle surface had either decreased in size or had disappeared. A pink coloration had developed which increased in intensity towards the base of the follicle. The follicle wall was thicker, and less fragile in appearance. By Days 9 to 11 the follicles were reduced in size (9 to $18 \mathrm{~mm}$ diameter) and in most cases were completely opaque and difficult to distinguish macroscopically from a GL. The sixth large follicle $(10 \mathrm{~mm}$ diameter) had become densely haemorrhagic at the Day 5 observation and thereafter decreased in size and turgor.

The 6 to $7 \mathrm{~mm}$ diameter follicles on Days 3 to 4 were thin-walled and fragile but did not show any clear area. At subsequent laparotomies these follicles gradually became reduced in size, less prominent and more flaccid.

Histological examination showed that the 10 to $15 \mathrm{~mm}$ diameter follicles were still vesicular but contained a 1 to $3 \mathrm{~mm}$ layer of apparently normal luteal tissue covering all except the apex of the follicle. Luteinization was absent in the 6 to $7 \mathrm{~mm}$ diameter follicles. The coexistent CL all appeared functional.

These observations confirm that under certain undefined, and presumably rare circumstances, large, intact follicles may luteinize in the sheep, and could be confused with normal CL.

\section{REFERENCES}

Grant, R. (1934) Trans. R. Soc. Edinb. 58, 36-47.

Moore, N. W., Rowson, L. E. A. \& Short, R. V. (1960) F. Reprod. Fert. 1, 332-349.

Robinson, T. J. (1950) F. agric. Sci., Camb. 40, 275-307.

Uptake of ferritin and carbon by the mouse uterus. J. H. STANTON and M. S. R. Sмrтн, School of Anatomy, University of New South Wales, Kensington, N.S.W. 2033, Australia.

Movement of tracer materials from the uterine lumen of non-pregnant female mice was studied in relation to the mechanisms of uptake and subsequent removal from the uterine luminal epithelium.

Ferritin and suspended carbon particles were injected $(0 \cdot 1 \mu \mathrm{l})$ intraluminally into the uterus of normal cyclic mice and the uteri were removed at intervals of 2, 5, 10 and $40 \mathrm{~min}, 4 \mathrm{hr}$ and $18 \mathrm{hr}$. Ovariectomized animals were injected subcutaneously with progesterone $(500 \mu \mathrm{g})$, injected with ferritin and the uteri removed 24 to $60 \mathrm{hr}$ later. The tissue injected with ferritin was processed for light and electron microscopy. Tissue injected with carbon was processed for light microscopy.

After $10 \mathrm{~min}$, ferritin and carbon had been transferred into the cytoplasm of certain cells of the epithelium. Ferritin was also present in macrophages immediately below the epithelium, in the endometrium and in the myometrium. Carbon particles could be seen in the macrophages close to the basal laminae. Removal of ferritin or carbon from the uterine lumen appeared to be independent of the stage of the oestrous cycle.

In ovariectomized animals treated with a single dose of progesterone, ferritin was retained in the epithelium in significant concentrations for up to $24 \mathrm{hr}$ after the progesterone treatment.

In both normal and ovariectomized mice, ferritin was still present in macrophages in the stroma up to $60 \mathrm{hr}$ after the ferritin injection. 
The use of Turnbull's Blue stain for Iron (II) on tissue injected with ferritin failed to detect any Iron II. This may indicate that the ferritin was not significantly reduced in its passage through the epithelial cell.

The experiments show that there exists a mechanism for the rapid removal of ferritin and carbon from the lumen of the uterus in non-pregnant mice. Luminal epithelial cells are capable of absorbing the material and it is then removed from the epithelium by macrophages in the underlying stroma. Progesterone may have some rôle in retaining this absorbed material in the epithelium.

\section{SESSION 7}

\section{Female Reprodugtion}

\section{Chairman: DR D. M. DE KRETSER}

The selective demonstration of hypothalamic nuclei involved in FSH-RF production. D. A. SAinsbury and P. M. Young, Department of Anatomy, University of Adelaide, South Australia 5000, Australia.

The localization of hypothalamic nuclei involved in the production of FSH-RF in rats was studied by observing the effects of selective destruction of testicular germinal epithelium upon thyamine pyrophosphatase (TPPase) activity.

Male Wistar rats (average body weight, $300 \mathrm{~g}$ ) were given a single intraperitoneal injection of $10 \mathrm{mg}$ Busulphan (Myleran, 1,4-dimethane-sulphonoxybutane, Burroughs Wellcome \& Co.) suspended in arachis oil per $\mathrm{kg}$ body weight. Busulphan alkylates chromosomal material and therefore inhibits spermatogonial development. The animals were killed 6 weeks later, and their hypothalami were sectioned in a cryostat and stained for TPPase by the method of Novikoff \& Goldfischer (1961). The testes were also fixed and routinely sectioned and stained with haematoxylin and eosin.

In control animals, basal levels of TPPase were found in the magnocellular paraventricular, supraoptic and arcuate nuclei. Following treatment with Busulphan the reaction product of TPPase in the above three nuclei covered a larger area of the cell bodies. This demonstrated an increased functional involvement of the Golgi apparatus in these nuclei as has been demonstrated in activated paraventricular neurosecretory neurones at the ultrastructural level (Young, 1974). The Leydig cells in the testis were morphologically indistinguishable from those of the controls, and there were no spermatids and only occasional spermatocytes.

Previous work (Debeljuk \& Mancini, 1971) has shown pituitary FSH levels to be lowest 5 to 6 weeks after Busulphan injection. The absence of maturing spermatozoa probably leads to this marked depletion of pituitary FSH by an increase in the production of FSH-RF. We conclude, therefore, that the supraoptic, paraventricular and arcuate nuclei are intimately involved in the production of FSH-RF.

\section{REFERENGES}

Debeljux, L. \& Mancini, R. E. (1971) F. Reprod. Fert. 26, 247-250.

Novikoff, A. B. \& Goldpischer, S. (1961) Proc. natn. Acad. Sci. U.S.A. 47, 802-810.

Young, P. M. (1974) f. Anat. (in press). 
Response of spayed ewes to administration of gonadotrophinreleasing hormone (Gn-RH). Helen Hearnshaw, B. J. Restall and B. G. StarR, Department of Agriculture, C.S.I.R.O. Prospect, Sydney, N.S.W. 2148, Australia.

Various methods of administering Gn-RH to spayed ewes were examined with the aim of mimicking the preovulatory release of gonadotrophin from the pituitary of the ewe.

In the first experiment, twenty spayed ewes were treated as follows. Group 1: $50 \mu \mathrm{g} \mathrm{Gn}-\mathrm{RH}$ injected subcutaneously (s.c.); Group 2: $50 \mu \mathrm{g} \mathrm{Gn-RH} \mathrm{impreg-}$ nated in a vaginal sponge; Group 3:100 $\mathrm{g} \mathrm{Gn}-\mathrm{RH}$ in a vaginal sponge; Group 4: $50 \mu \mathrm{g} \mathrm{Gn}-\mathrm{RH}$ in a vaginal sponge plus $50 \mu \mathrm{g} \mathrm{Gn}-\mathrm{RH}$ s.c. 24 and $48 \mathrm{hr}$ after the insertion of the sponge; Group 5: $100 \mu \mathrm{g} \mathrm{Gn}-\mathrm{RH}$ in a vaginal sponge plus $50 \mu \mathrm{g} \mathrm{Gn}-\mathrm{RH}$ s.c. 24 and $48 \mathrm{hr}$ after insertion of the sponge. Six plasma samples were obtained for LH determination from all ewes following injection or insertion of sponges on Day 1, and again $24 \mathrm{hr}$ later (Day 2) and $48 \mathrm{hr}$ later (Day 3). Sponges were not removed until completion of the experiment. Plasma $\mathrm{LH}$ concentrations rose to a maximum of $67 \cdot 7 \pm 6 \cdot 4 \mathrm{ng} / \mathrm{ml}$ (mean \pm S.E.) following the single injection of $50 \mu \mathrm{g} \mathrm{Gn-RH}$. By 24 and $48 \mathrm{hr}$ after the Gn-RH injection, plasma $\mathrm{LH}$ had fallen to baseline levels. The 50 and $100 \mu \mathrm{g} \mathrm{Gn}-\mathrm{RH}$ vaginal sponges resulted initially in small releases of LH (maximum of $11.6 \pm$ $2 \cdot 0$ and $16 \cdot 0 \pm 2 \cdot 7 \mathrm{ng} / \mathrm{ml}$ ). The $100 \mu \mathrm{g} \mathrm{Gn}-\mathrm{RH}$ vaginal sponges also resulted in sustained elevated concentrations of LH on Days 2 and 3 when compared with the control and $50 \mu \mathrm{g}$ sponge groups. In Groups 4 and 5, similar LH releases occurred on Day 1 following insertion of the sponges; both groups then showed large $\mathrm{LH}$ releases following $50 \mu \mathrm{g}$ Gn-RH on Day 2 (maximum $56 \cdot 3 \pm 10 \cdot 9$ and $68 \cdot 8 \pm 6 \cdot 5 \mathrm{ng} / \mathrm{ml}$ ) and reduced LH releases on Day 3 following the second Gn-RH injection (maximum $31.3 \pm 5.5$ and $33.7 \pm 2.9 \mathrm{ng} / \mathrm{ml}$ ). Overall, the $100 \mu \mathrm{g}$ sponge plus injection produced a greater total release of $\mathrm{LH}$ than the $50 \mu \mathrm{g}$ sponge plus injection.

In the second experiment, multiple injections of $\mathrm{Gn}-\mathrm{RH}$ were given to fifteen spayed ewes as follows. Group A: $50 \mu \mathrm{g}$ Gn-RH s.c. at 6-hr intervals (five injections); Group B: $50 \mu \mathrm{g}$ Gn-RH s.c. at 2-hr intervals (thirteen injections); Group G: control ewes (no injections). Plasma samples for LH were obtained from all ewes before and for $34 \mathrm{hr}$ after the first injection. Control ewes had LH values which varied between 6 and $12 \mathrm{ng} / \mathrm{ml}$ with one ewe showing a small release of $\mathrm{LH}$ after $18 \mathrm{hr}$. Injections of Gn-RH initially evoked LH releases in Groups A and B (141.0 \pm 9.5 and $100 \cdot 4 \pm 8.3 \mathrm{ng} / \mathrm{ml}$ ). Ewes in Group A showed releases of $\mathrm{LH}$ of diminishing magnitude to each following injection of Gn-RH. Ewes in Group B exhibited a more sustained release of $\mathrm{LH}$ for the first $10 \mathrm{hr}$ but $\mathrm{Gn}-\mathrm{RH}$ administered after 10 to $14 \mathrm{hr}$ did not appear to cause further $\mathrm{LH}$ release.

In Groups A and B, the results could indicate either depletion of LH in the pituitary or refractoriness of the pituitary to repeated stimulation with Gn-RH. Thus, Gn-RH will release LH in spayed ewes when injected s.c., or given in a vaginal sponge. However, the only treatment which successfully mimicked the preovulatory $\mathrm{LH}$ release was multiple injections at 2-hr intervals. 
Responses by prepubertal ewes to gonadotrophin-releasing hormone. R. N. Tyrrell, B. G. Starr and B. J. Restall, Department of Agriculture, Sydney, N.S.W. 2148, Australia.

This experiment was conducted to determine if $\mathrm{Gn}-\mathrm{RH}$ could be used to stimulate reproductive activity in prepubertal ewes. Twenty-five Merino ewes, averaging 11 months of age and $31.5 \mathrm{~kg}$ liveweight, which had not previously exhibited oestrus and did not have a CL at laparotomy before the experiment, were allocated in equal numbers to five groups. (1) Control, no Gn-RH; (2) single subcutaneous (s.c.) injection of $50 \mu \mathrm{g} \mathrm{Gn-RH;} \mathrm{(3)} \mathrm{four} \mathrm{s.c.} \mathrm{injections}$ each of $12.5 \mu \mathrm{g}$ Gn-RH given within a period of $4 \mathrm{hr}$; (4) vaginal sponge containing $50 \mu \mathrm{g} \mathrm{Gn}-\mathrm{RH}$; (5) vaginal sponge containing $100 \mu \mathrm{g} \mathrm{Gn}-\mathrm{RH}$ (sponges were left in the vagina for $24 \mathrm{hr}$ ).

Treatments began $72 \mathrm{hr}$ after the first laparotomy. Plasma samples for the determination of $\mathrm{LH}$ were collected $2 \mathrm{hr}$ before and $1 \mathrm{hr}$ after the start of treatment and then a further four times at 90 -min intervals. In addition, samples were taken 24, 30 and $48 \mathrm{hr}$ after treatment. Laparotomies were again performed 4 days later. In the meantime, two vasectomized rams were placed with the ewes for detection of oestrus.

Seventeen of twenty treated ewes responded to $\mathrm{Gn}-\mathrm{RH}$ with rises in plasma LH. Peak values were reached by $60 \mathrm{~min}$ in all groups except the multiple injection group $(150 \mathrm{~min}$ ). Average peak responses were $62 \mathrm{ng} / \mathrm{ml}$ and $50 \mathrm{ng} / \mathrm{ml}$ for the single and multiple injection groups, respectively. Peak responses were lower in the sponge groups averaging $6 \mathrm{ng} / \mathrm{ml}$ and $15 \mathrm{ng} / \mathrm{ml}$ for the $50 \mu \mathrm{g}$ and $100 \mu \mathrm{g}$ groups, respectively. Of five ewes with fresh ovulations after treatment, two came from the $50 \mu \mathrm{g}$ sponge group and one from each of the other treatment groups. None of the control ewes ovulated. The two ewes from the injection groups which ovulated had the lowest LH response of their respective groups. In addition, no LH response was detected in the three ewes which ovulated in the sponge groups. Five ewes were detected in oestrus in the 8 weeks following treatment, but none of these had ovulated during the experiment. Two came from the control group.

The negative association between ovulation and $\mathrm{LH}$ response to $\mathrm{Gn}-\mathrm{RH}$ suggests that it is highly unlikely that the five ovulations noted were caused by Gn-RH treatment. They probably resulted from an endogenous $\mathrm{LH}$ release during the $72 \mathrm{hr}$ between the first laparotomy and the administration of treatments. The absence of a marked $\mathrm{LH}$ response in these ewes may be due to pituitary refactoriness after the endogenous $\mathrm{LH}$ release.

It is concluded that Gn-RH, administered by the routes and at the doses described here, does not stimulate reproductive activity in prepubertal ewes.

LH release by cows in response to Gn-RH during the post-partum period. L. J. Cummins, I. A. Cumming, M. A. Knight and R. A. S. Lawson, Department of Agriculture, Victoria, Pastoral Research Station, Hamilton and S.S. Cameron Laboratory, Werribee, Australia.

In Exp. 1, two lactating cows were each infused in the jugular vein with Gn-RH at a rate of $15 \mu \mathrm{g} / \mathrm{hr}$ for $4 \mathrm{hr}$ on two occasions during the post-partum period. 
Two jugular plasma samples, taken $\frac{1}{2} \mathrm{hr}$ apart before the infusion was begun, were assayed for progesterone (Cain \& co-authors, 1972), and LH concentrations were determined in samples taken at $\frac{1}{2} \mathrm{hr}$ intervals for $2 \mathrm{hr}$ after infusion began (Goding \& co-authors, 1969). Details of the treatments and results are shown in Table 1.

Table 1. Progesterone and maximum plasma LH concentrations in cows following Gn-RH infusion

\begin{tabular}{cccc}
\hline $\begin{array}{c}\text { No.of } \\
\text { cow }\end{array}$ & $\begin{array}{c}\text { Days } \\
\text { post partum }\end{array}$ & $\begin{array}{c}\text { Max. } L H \\
\text { conc. }(\mathrm{ng} / \mathrm{ml})\end{array}$ & Progesterone $(\mathrm{ng} / \mathrm{ml})$ \\
\hline 13 & 16 & 37 & $8 \cdot 3$ \\
& 30 & 50 & $8 \cdot 3$ \\
48 & 18 & 50 & $1 \cdot 8$ \\
& 32 & 50 & 3.55 \\
\hline
\end{tabular}

In Exp. 2, forty-eight 2-year-old Hereford heifers, which had been subjected to three planes of nutrition (low, medium and high) during late pregnancy and grazed together on good quality spring pasture after calving, were used. Between Days 1 and 46 post partum nineteen heifers were injected subcutaneously with $0.25 \mathrm{mg} \mathrm{Gn}-\mathrm{RH}$, and the remaining twenty-two received $0.5 \mathrm{mg}$ oestradiol intravenously. Jugular vein plasma samples taken $16 \mathrm{hr}$ before, and hourly for $8 \mathrm{hr}$ after, Gn-RH injection and $6 \mathrm{hr}$ before and 10, 13, 16 and $18 \mathrm{hr}$ after oestradiol injection, were assayed for $\mathrm{LH}$.

An immediate surge of LH which reached peak concentrations of 11 to $>50 \mathrm{mg} / \mathrm{ml}$ followed Gn-RH injection in all the animals. No relationships were evident between maximum LH concentration and post-partum interval, injection time or previous nutritional treatment. None of the oestradiol treated animals exhibited an $\mathrm{LH}$ release during the sampling period.

The evidence from these experiments suggests that in the immediate postpartum period the cow is capable of giving an LH release similar in magnitude to that found at normal oestrus (Cummins, Blockey, Brown \& Goding, 1972).

This responsiveness to Gn-RH is contrary to that reported in the ewe by Chamley, Findlay, Cumming, Buckmaster \& Goding (1974), and Chamley \& Parr (1973) found that pituitary LH was depleted in ewes during late pregnancy and the immediate post-partum period. The failure of oestradiol to cause an $\mathrm{LH}$ release such as occurs in ovariectomized cows (Cummins et al., 1972) may be explained by a blocking effect at the hypothalamic level by progestins secreted in post-partum cows (Tribble \& co-authors, 1973).

\section{REFERENGES}

Gain, M. D., Gerini, J. G., Gerini, M. E., Chamley, W. A., Gumming, I. A. \& Goding, J. R. (1972) 7. Reprod. Fert. 28, 148-150.

Ghamley, W. A., Findlay, J. K., Gumming, I. A., Buckmaster, J. M. \& Goding, J. R. (1974) Endocrinology, 94, 291-293.

Ghamley, W. A. \& Parr, R. A. (1973) Int. Res. Commun. Systems (73-12) 15-13-13.

Gummins, L. J., Blockey, M. A. DE B., BRown, J. M. \& Goding, J. R. (1972) F. Reprod. Fert. 28, 135-136.

Goding, J. R., Gatt, K. J., Brown, J. M., Kaltenbach, G. G., Gumming, I. A. \& Mole, B. J. (1969) Endocrinology, 85, 133-142.

Tribble, R. L., Sorensen, A. M., Woodward, T. L., Connor, J. S., Beverley, J. R. \& Fleeger, J. L. (1973) Nature, Lond. 246, 494-495. 
LH and FSH release in the gilt during oestrus and ovulation. J. K. Findlay, ${ }^{*}$ I. A. Cumming $\dagger$ and R. A. S. Lawson, $\dagger{ }^{*}$ Reproduction Research Section, University of Melbourne and $\dagger$ Department of Agriculture, S.S. Cameron Laboratory, Werribee 3030, Australia.

Effect of live weight and plane of nutrition on FSH secretion and clearance in the ewe. I. A. Cumming, J. K. FindlaY* and R. B. Baxter, Department of Agriculture, Victoria and ${ }^{*}$ University of Melbourne, S.S. Cameron Laboratory, Werribee, Victoria 3030, Australia.

A positive relationship exists between live weight and ovulation rate in mature ewes (Cumming, 1972). The rôle of FSH in this relationship was examined in ewes with different live weights.

Initially, plasma concentrations of FSH were estimated in ewes on three planes of nutrition. Corriedale ewes ( 5 years old, mean live weight $42 \mathrm{~kg}$ ) were allotted to three groups according to live weight, penned individually and fed daily from 23 February 1973 one-third maintenance (M), $M$ and $2 \mathrm{M}$ rations of lucerne chaff. Daily checks for oestrus began $20 \mathrm{March}$; four ewes of Group $1 / 3 \mathrm{M}$ failed to mate. Ewes were bled hourly from the jugular vein for 7 to 10 hr on 10,13,14 and 17 April and plasma was assayed for FSH (Salamonsen \& co-authors, 1973). Groups $1 / 3 \mathrm{M}(\mathrm{N}=16), \mathrm{M}(\mathrm{N}=12)$ and $2 \mathrm{M}(\mathrm{N}=9)$ had mean live weights at 14 April of 35,42 and $49 \mathrm{~kg}$, and mean ovulation rates at 18 April of $0.94,1.17$ and 1.90, respectively. Concentrations of FSH in each ewe tended to be constant except about oestrus when the preovulatory release occurred. A large variation occurred between animals within each treatment group such that mean concentrations $( \pm$ S.E., $\mathrm{ng} / \mathrm{ml}$ ) of FSH for ewes which mated in each group were not significantly different $(1 / 3 \mathrm{M}, 75 \pm 6 \cdot 6, \mathrm{~N}=12$; $M, 69 \pm 6 \cdot 2, N=12 ; 2 M, 65 \pm 5 \cdot 0, N=9)$. Ewes with two CL tended to have a higher FSH level than those with one CL (one CL, $65 \pm 7 \cdot 1, N=21$, versus two $\mathrm{CL}, 78 \pm 9 \cdot 9, \mathrm{~N}=12)$, but this difference was not significant $(P \geqslant 0 \cdot 15)$.

In the second experiment, Corriedale ewes (5 years old, mean live weight $47 \mathrm{~kg}$ ), each with a carotid skin loop, were treated as described above. Six weeks later, ewes from each group were given a loading injection $(2 \mathrm{mg})$ and then infused with NIH-FSH-S6 ( $1 \mathrm{mg} / \mathrm{hr}$ for $6 \mathrm{hr}$ ) into the jugular vein on Days 10 to 12 of the oestrous cycle and bled from the carotid artery. Two days later, Gn-RH (Abbott) was infused $\left(2.5 \mu \mathrm{g} / \mathrm{hr}\right.$ ) into the carotid artery for $4 \frac{1}{2}$ $\mathrm{hr}$ and blood was withdrawn from the jugular vein. Ovaries were examined 2 days after $\mathrm{Gn}-\mathrm{RH}$ treatment.

Groups $1 / 3 \mathrm{M}, \mathrm{M}$ and $2 \mathrm{M}$ had respective mean live weights of $41(\mathrm{~N}=4)$, $46(\mathrm{~N}=5)$ and $51 \mathrm{~kg}(\mathrm{~N}=5)$ and mean metabolic clearance rates (MCR) $(\mathrm{ml} / \mathrm{min} / \mathrm{kg} ; \pm$ S.E. $)$ of $0.91(\mathrm{~N}=2), 0.62 \pm 0.02(\mathrm{~N}=4)$ and $0.80 \pm 0.02(\mathrm{~N}=3)$, respectively, which corresponded to secretion rates $(\mu \mathrm{g} / \mathrm{min} / \mathrm{kg})$ of $0.03,0.06$ and 0.04 , respectively. Mean response indices ( \pm S.E.) of Gn-RH-induced FSH release were $447 \pm 110(\mathrm{~N}=4), 338 \pm 69(\mathrm{~N}=4)$ and $226 \pm 88(\mathrm{~N}=5)$, respectively.

Ewes with one CL had a higher FSH response to Gn-RH (one CL, $395 \pm 67$, $\mathrm{N}=9$; two $\mathrm{CL}, 179 \pm 38, \mathrm{~N}=4$ ) and a higher MCR (one $\mathrm{CL}, 0 \cdot 80 \pm 0 \cdot 07$, 
$\mathrm{N}=4$; two $\mathrm{CL}, 0.69 \pm 0.06, \mathrm{~N}=5$ ) than ewes with two $\mathrm{CL}$, but the differences were not significant $(P \geqslant 0 \cdot 10)$.

The results do not support the concept that ovulation rate is related to peripheral FSH concentration.

\section{REFERENCES}

Gumming, I. A. (1972) Ph.D. thesis, University of Melbourne.

Salamonsen, L. A., Jonas, H. A., Burger, H. G., Buckmaster, J. M., Chamley, W. A., Gumming, I. A., Findlay, J. K. \& Goding, J. R. (1973) Endocrinolog', 93, 610-618.

Ovulation in ewes selected for fecundity: effect of Gn-RH injected on the day of oestrus. B. M. Bindon, C.S.I.R.O. Division of Animal Genetics, P.O. Box 90, Epping, N.S.W. 2121, Australia.

It is known that synthetic Gn-RH causes prompt release of LH in ewes and that the response is greater following injection on the day of oestrus than at other stages of the oestrous cycle. The present study was designed to examine whether such $\mathrm{LH}$ release is capable of increasing the number of eggs shed by Merino ewes from four genetic groups.

The animals were aged 3 to 6 years at the time of the study (May 1973) and were drawn from the ' $\mathrm{C}$ ', ' $\mathrm{O}$ ', ' $\mathrm{T}$ ' and ' $\mathrm{B}$ ' flocks which are, respectively, random-bred controls and lines selected for low, medium and high litter size. Stage of the oestrous cycle was established by daily ( 09.00 hours) observations for one complete cycle. At 09.00 hours on the day of the next oestrus, the ewes were given intramuscular injections of either $0.9 \% \mathrm{NaCl}$ or $100 \mu \mathrm{g}$ synthetic Gn-RH (Hoechst). The number of ovulations was assessed at laparotomy 4 days later. Jugular blood samples were taken $1 \mathrm{~min}$ before injection and 60 min later, and LH levels measured by radioimmunoassay.

Results are presented in Table 1. In none of the flocks was there evidence that the Gn-RH caused extra ovulations, despite substantial releases of LH at the time when $\mathrm{LH}$ levels were falling in uninjected ewes.

Table 1. Ovulation and $\mathrm{LH}$ response to Gn-RH injected on the day of oestrus

\begin{tabular}{|c|c|c|c|c|c|}
\hline \multirow[t]{2}{*}{ Flock } & \multirow[t]{2}{*}{ Treatment } & \multirow{2}{*}{$\begin{array}{l}\text { No. of } \\
\text { ewes }\end{array}$} & \multirow{2}{*}{$\begin{array}{l}\text { Mean no. } \\
\text { ovulations }\end{array}$} & \multicolumn{2}{|c|}{$\begin{array}{l}\text { LH change }(\mathrm{ng} / \mathrm{ml}) \text { between } \\
-1 \text { and }+60 \text { min of injection }\end{array}$} \\
\hline & & & & Mean & Range \\
\hline G & $\begin{array}{c}\text { Saline (S) } \\
\text { Gn-RH(100 } \mu \mathrm{g})\end{array}$ & $\begin{array}{l}10 \\
10\end{array}$ & $\begin{array}{l}1 \cdot 2 \pm 0 \cdot 1 \\
1 \cdot 3 \pm 0.2\end{array}$ & $\begin{array}{l}-2 \cdot 7 \\
+27 \cdot 9\end{array}$ & $\begin{array}{l}-5 \cdot 0 \text { to } 0 \cdot 0 \\
+14 \cdot 4 \text { to }+39 \cdot 0\end{array}$ \\
\hline O & $\underset{\mathrm{Gn}-\mathrm{RH}}{\mathrm{S}}$ & $\begin{array}{l}13 \\
14\end{array}$ & $\begin{array}{l}1.2 \pm 0.2 \\
1.3 \pm 0.1\end{array}$ & $\begin{array}{l}-11 \cdot 2 \\
+22 \cdot 6\end{array}$ & $\begin{array}{l}-36.3 \text { to }+6 \cdot 0 \\
+5.5 \text { to }+46.5\end{array}$ \\
\hline $\mathbf{T}$ & $\underset{\text { Gn-RH }}{S}$ & $\begin{array}{r}11 \\
9\end{array}$ & $\begin{array}{l}1 \cdot 9 \pm 0.1 \\
1.7 \pm 0.2\end{array}$ & $\begin{array}{l}-4 \cdot 5 \\
+88 \cdot 9\end{array}$ & $\begin{array}{l}-21 \cdot 4 \text { to }+12 \cdot 8 \\
+34 \cdot 4 \text { to }+143 \cdot 4\end{array}$ \\
\hline B & $\underset{\text { Gn-RH }}{S}$ & $\begin{array}{l}11 \\
11\end{array}$ & $\begin{array}{l}2 \cdot 9 \pm 0 \cdot 5 \\
2 \cdot 9 \pm 0 \cdot 5\end{array}$ & $\begin{array}{l}+12 \cdot 5 \\
+22 \cdot 9\end{array}$ & $\begin{array}{l}-9 \cdot 0 \text { to }+83 \cdot 5 \\
-35 \cdot 3 \text { to }+104 \cdot 6\end{array}$ \\
\hline
\end{tabular}

This experiment was repeated on the same animals 6 weeks later using $\mathrm{Gn}-\mathrm{RH}$ at a dose of $500 \mu \mathrm{g}$ per ewe. Ovulation rate was again unaffected. 
Although more careful timing of $\mathrm{Gn}-\mathrm{RH}$ injection in relation to the normal preovulatory LH peak may give better results, it appears unlikely that this substance can be used to augment the natural level of ovulations. The results also suggest that a deficiency of LH on the day of oestrus is not one of the factors limiting the number of eggs shed in flocks like the ' $\mathrm{C}$ ' and ' $\mathrm{O}$ ' with genetically low fecundity.

\section{Session 8 \\ Prostaglandins}

\section{Chairman: Associate Professor T. N. EDEY}

Luteal function in the ewe after injection of prostaglandin $F_{2 \alpha}$ directly into the corpus luteum. W. A. GhamleY* and J. D. O'SheA, $\dagger^{*}$ Reproduction Research Section, Department of Physiology, and $\dagger$ Department of Veterinary Preclinical Sciences, University of Melbourne, Victoria, Australia.

Prostaglandin $\mathrm{F}_{2 \alpha}\left(\mathrm{PGF}_{2 \alpha}\right)$ has been shown to cause luteolysis in the ewe when infused into the ovarian artery (Chamley \& co-authors, 1972) or uterine vein (Chamley, Cerini, Cerini, Cumming, Goding \& O'Shea, 1974). Little is known about the mechanisms by which $\mathrm{PGF}_{2 \alpha}$ exerts this effect.

Five groups of Merino ewes were included in this present study. Details of the sheep and the treatments given are shown in Table 1. On the day of treatment, sheep in Groups 1 to 4 underwent laparotomy. In the treated groups, saline or $\mathrm{PGF}_{2 \alpha}$ was injected into the CL by means of a 25- $\mu$ l Hamilton gas chromatograph syringe.

Table 1. Details of animals and solutions injected directly into the $\mathrm{CL}$

\begin{tabular}{cccc}
\hline Group & No. of animals & $\begin{array}{c}\text { Day of treatment } \\
\text { (oestrus }=\text { Day 1) }\end{array}$ & Treatment \\
\hline 1 & 3 & 7 to 8 & Saline \\
2 & 4 & 7 to 8 & $60 \mu \mathrm{PGF}_{2 a}$ \\
3 & 5 & 7 to 8 & $120 \mu \mathrm{g} \mathrm{PGF}_{2 \alpha}$ \\
4 & 7 & 8 to 9 & $240 \mu \mathrm{g} \mathrm{PGF}_{2 \alpha}$ \\
5 & 4 & 7 to 8 & None \\
\hline
\end{tabular}

In Groups 1 to 4 , peripheral plasma samples were collected from $24 \mathrm{hr}$ before treatment up to $84 \mathrm{hr}$ after treatment. Plasma samples were assayed for progesterone by competitive protein-binding (Cain \& co-authors, 1972). Animals underwent a second laparotomy 60 to $84 \mathrm{hr}$ after treatment and the ovary bearing the CL was removed for histological study.

Saline or $\mathrm{PGF}_{2 \alpha}$ failed to suppress luteal function over a long period. For Groups 1 to 4 , progesterone levels in the control period were $4 \cdot 1 \pm 1 \cdot 2,4 \cdot 7 \pm$ $2.3,1.8 \pm 1.0$ and $2.4 \pm 1.2 \mathrm{ng} / \mathrm{ml}$, respectively (mean \pm S.D.). There was a transient fall in circulating progesterone in these groups during the first $6 \mathrm{hr}$ 
after treatment but by $24 \mathrm{hr}$ after treatment, progesterone levels in Groups 1 to 3 were $3 \cdot 5 \pm 2 \cdot 7,3 \cdot 3 \pm 2 \cdot 6$ and $2 \cdot 1 \pm 1 \cdot 9 \mathrm{ng} / \mathrm{ml}$, respectively. In Group 4, plasma progesterone concentration rose dramatically to a peak level of $8 \cdot 8 \pm$ $3.6 \mathrm{ng} / \mathrm{ml} 48 \mathrm{hr}$ after treatment.

In two sheep (one from each of Groups 2 and 4), the CL had regressed. In all others from Groups 1 to 3, the histological appearance of the CL was normal and consistent with the GL histology for untreated animals (Group 5). In Group 4, GL were either normal or showed signs of very early regression.

These results, which are in contrast to the known luteolytic effect which $\mathrm{PGF}_{2 \alpha}$ exerts when it is perfused through the ovary, suggest that a vascular component might be involved in the overall mechanism of action of the prostaglandin. The reason for the marked stimulation of progesterone secretion which was observed in animals treated with the highest dose (Group 4) is unclear, but it may represent a parallel situation to that in studies in vitro (Speroff \& Ramwell, 1970) in which pharmacological doses of PGF $_{2 \alpha}$ were used.

\section{REFERENGES}

Ghamley, W. A., Buckmaster, J. M., Gain, M. D., Gerini, J. G., Gerini, M. E., Gumming, I. A. \& Goding, J. R. (1972) J. Endoct. 55, 253-263.

Ghamley, W. A., Cerini, J. G., Cerini, M. E. D., Gumming, I. A., Goding, J. R. \& O’Shea, J. D. (1974) Biol. Reprod. 11, 191-197.

Gain, M. D., Gerini, J. G., Gerini, M. E., Ghamley, W. A., Gumming, I. A. \& Goding, J. R. (1972) 7. Reprod. Fert. 28, 148-150.

Speroff, L. \& Ramwell, P. W. (1970) 7. clin. Endocr. Metab. 30, 345-350.

Morphology of the corpus luteum during normal and prostaglandininduced luteolysis in the sheep. B. D. Stacy, R. T. Gemmell and G. D. Thorburn, C.S.I.R.O., Division of Animal Physiology, Prospect, N.S.W., Australia, and Nuffeld Institute for Medical Research, Oxford, England.

Ultrastructural characteristics of the CL during normal regression have been examined and used as a basis for comparing the induced pattern of morphological changes observed in the luteal cells after administration of prostaglandin $\left(\mathrm{PGF}_{2 \alpha}\right)$ at Day 10 of the oestrous cycle in the sheep (oestrus = Day 1). Infusions of $\mathrm{PGF}_{2 \alpha}(40 \mu \mathrm{g} / \mathrm{hr})$ into the uterine vein were given for various lengths of time ( $\frac{1}{2}$ to $6 \mathrm{hr}$ ). Blood samples were taken for hormone assay and ovaries were fixed by intravascular perfusion with glutaraldehyde at 0,24 and $48 \mathrm{hr}$ after infusion.

The formation and secretion of small densely staining granules (about $0.2 \mu \mathrm{m}$ diameter) correlates remarkably well with the known changes in the rate of progesterone secretion by the CL of the sheep during the cycle (Gemmell, Stacy \& Thorburn, 1974). Maximum secretion of granules occurred on Days 10 to 11 of the cycle and this was followed by progressive decline in secretory activity on Days 12 to 15 . This decreased secretory activity together with the appearance of autophagocytic bodies (organelles associated with degradation) in the luteal cells at Day 12 constituted the first structural signs of luteolysis. From Day 12 to Day 14 there may have been a slight increase in the number of degradation organelles, but on Day 15 more obvious signs of luteal regression 
became apparent. At this time the cells had begun to shrink, lipid droplets were profusely distributed throughout the cytoplasm and there were numerous signs of cellular breakdown.

After infusion of $\mathrm{PGF}_{2 \alpha}$ for $6 \mathrm{hr}$ there was an abrupt decrease in the concentration of progesterone in peripheral plasma, and the fine structure of the CL showed that this change in hormonal status was accompanied by cessation of granule secretion by the luteal cells. Autophagocytic bodies could be detected immediately after the infusion and $24 \mathrm{hr}$ later there were signs of lipid accumulation together with cellular shrinkage and disorganization; these signs advanced to the stage of complete regression $48 \mathrm{hr}$ after the infusion.

A close parallelism may be drawn between the changes in granule secretion and peripheral plasma concentrations during the oestrous cycle and also when the hormone levels are altered by the infusion of $\mathrm{PGF}_{2 \alpha}$. The progressive structural changes observed within the luteal cells undergoing normal regression can be induced in sheep at Day 10 of the oestrous cycle by the infusion of PGF $2 \alpha$.

\section{REFERENGE}

Gemmel. , R. T., Stacy, B. D. \& Thorburn, G. D. (1974) f. Reprod. Fert. 36, 444-445.

\section{Intramuscular administration of a prostaglandin analogue during} pregnancy in the goat. P. J. Holst and C. D. NANGarrow, Department of Agriculture, Condobolin 2877, and C.I.S.R.O., Division of Animal Physiology, Prospect, N.S.W. 2148, Australia.

Prostaglandin analogue I.C.I. 79,939 was administered intramuscularly to pregnant goats to assess its experimental usefulness as an abortifacient.

Of eighteen bush goats mated in April and May at Condobolin Research Station, thirteen were considered pregnant to the initial mating. The prostaglandin analogue was administered at either $16 \mu \mathrm{g}$ or $32 \mu \mathrm{g}$ to pairs of goats at one of several stages of pregnancy. These corresponded to 2, 3, 4 or 5 months of pregnancy, the latter being 143 days after mating. A control pair of goats at the same stage of pregnancy was penned with the treated goats at the 2- and 3-month stages to detect spontaneous abortion as a result of the stress of penning.

Peripheral blood samples were taken from the jugular vein before treatment and thereafter at 12-hr intervals until after abortion. Visual observations were made at not more than $6 \mathrm{hr}$ intervals.

All goats aborted as a result of the prostaglandin treatment regardless of dose level or stage of pregnancy. Control goats were unaffected by penning and pregnancy was subsequently confirmed by laparotomy. The mean time interval from administration of prostaglandin to the delivery of the first fetus for goats at 2, 3, 4 or 5 months of pregnancy was $68,58,40$ and $46 \mathrm{hr}$, respectively.

Progesterone concentration in peripheral blood indicated an abrupt decline in circulating progesterone in the first $12 \mathrm{hr}$ after prostaglandin administration. For goats at 2, 3 or 4 months of pregnancy, progesterone levels declined from a mean of $12.9 \mathrm{ng} / \mathrm{ml}$ before treatment to a mean of $2.1 \mathrm{ng} / \mathrm{ml} 12 \mathrm{hr}$ later, then to $0.9 \mathrm{ng} / \mathrm{ml}$ at the time of abortion. Goats treated at 143 days after mating had a mean progesterone level of $11.1 \mathrm{ng} / \mathrm{ml}$ at the time of treatment and 4.9 $\mathrm{ng} / \mathrm{ml} 12 \mathrm{hr}$ later. 
These data indicate that the administration of the prostaglandin analogue I.C.I. 79,939 will readily cause abortion in goats at all stages of pregnancy. The progesterone data suggest that the abortion was a result of luteal regression.

Use of oestradiol benzoate to improve synchronization of oestrus in cattle. G. D. NANCarrow and H. M. RADFord, C.S.I.R.O. Division of Animal Physiology, Prospect, N.S.W. 2148, Australia.

Following luteolysis induced by prostaglandin $\mathrm{F}_{2 \alpha}\left(\mathrm{PGF}_{2 \alpha}\right)$ or its analogues, cows return to oestrus within 2 to 5 days of treatment. It would be desirable to reduce the periods during which oestrus and subsequent ovulation occur so that insemination could be undertaken at a predetermined time after prostaglandin treatment. Accordingly, we chose to examine the effect of oestrogen, given during the course of prostaglandin-induced luteolysis, on the time of occurrence of oestrus and the endocrine events that succeed the use of prostaglandins.

Twenty cows of mixed breeds in which oestrus had been synchronized with a PGF ${ }_{2 \alpha}$ analogue (I.C.I. 80,996) given 13 days earlier, were injected subcutaneously with $500 \mu \mathrm{g}$ I.C.I. 80,996. Twenty-eight hours later, half the cows were injected intramuscularly with $500 \mu \mathrm{g}$ oestradiol benzoate (OB). Blood samples were collected at the time of injection of I.C.I. 80,996, and at 4-hr intervals for 3 days from the time of $O B$ injection, then twice daily for the next 6 days. Plasma was assayed for LH and progesterone. The cows were checked carefully for oestrus.

Eight of the ten OB-treated, and nine of the other cows, experienced oestrus within $120 \mathrm{hr}$ of injection of I.C.I. 80,996. Treatment with OB significantly shortened the times (mean $\mathrm{hr} \pm$ S.D.) to onset of oestrus $(52.9 \pm 6.7$ versus $74.6 \pm 20.9 ; P<0.01)$ and to peak secretion of $\mathrm{LH}(54.3 \pm 4.5$ versus $77 \cdot 3 \pm 21 \cdot 0$; $P<0.005$ ). The interval from OB injection to the LH peak was $26 \cdot 3 \pm 4.5 \mathrm{hr}$. There was no difference between OB-treated and control cows in the interval from onset of oestrus to peak secretion of $\mathrm{LH}(P>0 \cdot 3)$. Progesterone concentrations $(\mathrm{ng} / \mathrm{ml})$ in plasma collected at 2, 4 and 6 days following individual $\mathrm{LH}$ peaks were, for OB-treated and control cows respectively, $0 \cdot 6 \pm 0 \cdot 2,0 \cdot 5 \pm 0 \cdot 2$ $(P>0.3) ; 1 \cdot 1 \pm 0.6,2 \cdot 1 \pm 0.6(P<0.01) ; 3.6 \pm 2.9,3.4 \pm 0.9(P>0.8)$. The OBtreated and control cows returned to oestrus 20 to 22 days and 17 to 23 days later, respectively.

The results indicate that this particular use of OB improved the synchronization of oestrus in prostaglandin-treated cattle, and suggest that there was no adverse effect of the treatment on the oestrous cycle. Fertility remains to be determined following insemination based either on detection of oestrus or on a fixed time basis. 